Sains Malaysiana 49(2)(2020): 271-281

http://dx.doi.org/10.17576/jsm-2020-4902-05

\title{
Integrated Nitrogen Management in Increasing Yield and Economic Profitability of Broccoli (Brassica oleracea var. italica L.)
}

(Pengurusan Integrasi Nitrogen dalam Meningkatkan Hasil dan Keuntungan Ekonomi Brokoli (Brassica oleracea var italica L.))

\author{
Md. Jamal Hussain, A.J.M. Sirajul Karim, A.R.M. Solaiman, MD. Monirul Islam, Md. Shafiqul Islam \& \\ LAILA NAHER*
}

\section{ABSTRACT}

The experiment was conducted at Bangabandhu Sheikh Mujibur Rahman Agricultural University during the period of November 2014 to April 2015 with a view to assess the combined effect of inorganic and organic sources of nitrogen on yield of broccoli and to develop a combined dose under integrated plant nutrition system (IPNS) for broccoli production.

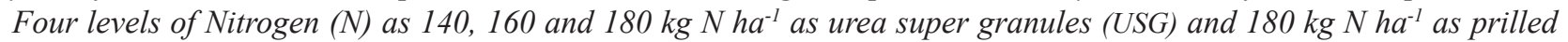
urea (PU) as well as three different organic nitrogen sources (IPNS based) were considered to comprise 24 treatments combinations. The experiment was laid out in a randomized complete block design with three replications. USG along with organic manures showed better yield performance regarding yield attributes and yield compared to PU. The

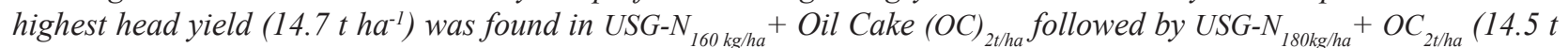

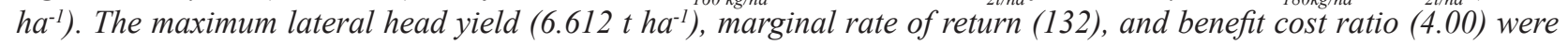
recorded in USG-N $N_{160 \mathrm{kgha}}+$ Poultry manure $(P M)_{3 t h a}$. The treatment $P U-N_{180}+P M_{3}$ also showed better performance regarding yield (13.7 $\left.\mathrm{tha}^{-1}\right)$, harvest index (27.1\%) and benefit cost ratio (BCR) (3.84). Therefore, USG@160 kg Nha-1 +3 t ha $a^{-1}$ poultry manure as adjusted $N_{126} P_{22} K_{62} S_{14} Z n_{2} B_{1} M o o_{0.8} \mathrm{~kg} / \mathrm{ha}+3 \mathrm{t} / \mathrm{ha} P M$ or PU@180 kg N/ha+3 t/ ha poultry manure as adjusted $\mathrm{N}_{146} \mathrm{P}_{22} \mathrm{~K}_{62} \mathrm{~S}_{14} \mathrm{Zn}_{2} \mathrm{~B}_{1} \mathrm{Mo}_{0.8} \mathrm{~kg} / \mathrm{ha}+3 \mathrm{t} / \mathrm{ha} \mathrm{PM}$ can be recommended for broccoli production in Grey Terrace Soil.

Keywords: Broccoli; head yield; organic manure; prilled urea; urea super granules

\section{ABSTRAK}

Suatu uji kaji telah dijalankan di Universiti Pertanian Bangabandhu Sheikh Mujibur Rahman antara November 2014 hingga April 2015 dengan tujuan untuk menilai kesan gabungan sumber tak organik dan organik nitrogen kepada hasil brokoli dan untuk membangunkan dos gabungan di bawah sistem integrasi nutrisi tanaman (ipns) untuk pengeluaran brokoli. Empat tahap Nitrogen (N) iaitu 140, 160 dan $180 \mathrm{~kg} \mathrm{~N} \mathrm{ha}^{-1}$ sebagai urea super granul (USG) dan $180 \mathrm{~kg} \mathrm{~N} \mathrm{ha-1}$ sebagai urea prill (PU) serta tiga nitrogen organik berbeza sumber (berasaskan IPNS) telah diambil kira terdiri daripada 24 gabungan rawatan. Uji kaji tersebut telah dibentangkan dalam reka bentuk blok lengkap dengan tiga replikasi. USG berserta baja organik menunjukkan prestasi hasil yang lebih baik daripada atribut hasil dan hasil berbanding PU.

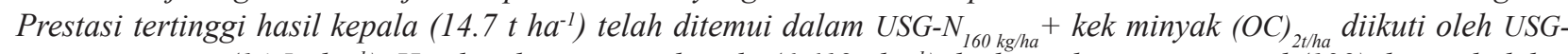
$N_{180 \mathrm{kgha}}+O C_{2 t h a}\left(14.5 \mathrm{t} \mathrm{ha}^{-1}\right)$. Hasil maksimum sisi kepala (6.612 $\left.\mathrm{th}^{-1}\right)$, kadar pulangan marginal (132) dan nisbah kos manfaat (4.00) telah direkodkan dalam USG-N $N_{160 \mathrm{~kg} h a}+$ baja ayam (PM) ${ }_{3 t \text { tha }}$. Rawatan $P U-N_{180}+P_{3}$ juga menunjukkan prestasi yang lebih baik mengenai hasil (13.7 t ha $\left.\mathrm{t}^{-1}\right)$, indeks tuaian (27.1\%) dan nisbah kos faedah (BCR) (3.84). Oleh itu, USG@160 kg Nha $a^{-1}+3 t h a^{-1}$ baja ayam sepertiyang dilaraskan $N_{126} P_{22} K_{62} S_{14} Z n_{2} B_{1} M O_{0.8} \mathrm{~kg} / \mathrm{ha}+3 \mathrm{t} / \mathrm{ha} P M$ atau $P U @ 180 \mathrm{~kg} \mathrm{~N} \mathrm{ha-1}+3$ t/ha baja ayam seperti yang dilaraskan $N_{146} P_{22} K_{62} S_{14} \mathrm{Zn}_{2} B_{1} M_{0.8} \mathrm{~kg} / \mathrm{ha}+3 \mathrm{t} / \mathrm{ha} P M$ boleh disyorkan untuk pengeluaran brokoli dalam tanah Teres Kelabu.

Kata kunci: Baja organik; brokoli; hasil kepala; urea prilled; urea super granul

\section{INTRODUCTION}

Broccoli is an important vegetable crop and has high nutritional and good commercial value (Yoldas et al. 2008). It is low in sodium food, fat free and calories, high in vitamin $\mathrm{C}$ and good source of vitamin $\mathrm{A}$, vitamin $\mathrm{B}_{2}$ and calcium (Decoteau 2000). But its expansion is very slow due to its low yield and lack of awareness to its consumption technique by the mass people in Bangladesh. Imbalanced fertilizer management is the major problem among the various reasons behind the low yield of broccoli as a high value crop. Nitrogen plays an important role in broccoli production and broccoli is highly dependent on $\mathrm{N}$ fertilization to achieve a good yield (Babik \& Elkner 2002; Belec et al. 2001). However, sustainable production of crops cannot be maintained by using chemical fertilizers alone or only by organic manures. It is necessary to use 
fertilizer and manure in an integrated way in order to obtain sustainable crop yield without affecting soil fertility.

Nitrogen is an important plant nutrient and is the most limiting due to its high mobility and different types of losses (Zaman et al. 1993). To control this loss, USG application may be a good option to regulate the extent of $\mathrm{NH}_{3}$ volatilization and minimize production cost as well as to increase crop yield. $20 \%$ urea could be saved by the use of USG instead of PU for cabbage, cauliflower and brinjal (eggplant) using USG at the rate of $370 \mathrm{~kg}, 220 \mathrm{~kg}$ and $165 \mathrm{~kg} \mathrm{~N} \mathrm{ha}^{-1}$, respectively. Ouda and Mahadeen (2008) reported that regardless of organic manure doses, using the higher doses of inorganic fertilizer produced higher yields of main, lateral and total heads compared with control which followed the same trend in response to combine dose of organic manure and inorganic fertilizers. Moreover, organic manure can serve as an alternative practice to mineral fertilizers for improving soil structure (Dauda et al. 2008) and microbial biomass (Suresh et al. 2004). Cow dung, poultry manure and mustard oilcake are considered as the largest components and rich sources of organic matter and plant nutrients. Many reports showed that poultry manure is the source of $\mathrm{N}, \mathrm{P}$ and $\mathrm{K}$ that can improve soil fertility (Sreelatha et al. 2006).

The use of cow dung poultry litter and mustard oil cake, and their proper management can help to reduce the need for chemical fertilizer use. But, sufficient research has not yet been carried out in the country regarding the available macronutrient release from mustard oil cake, cow dung and poultry manure and its integrated effect on broccoli. Therefore, utilization of locally produced organic manures with deep placement of USG could be a good approach to $\mathrm{N}$ management in broccoli production which may increase crop yields ensuring good quality with minimum use of chemical fertilizer. Keeping all this views in mind, the present study was undertaken to assess the combined effect of $\mathrm{N}$ as USG and PU along with different organic materials on yield and yield attributes of broccoli and to evaluate the economic performance and optimization of combined doses to develop an integrated plant nutrition system (IPNS) for sustainable broccoli production.

\section{MATERIALS AND METHODS}

LOCATION AND SOIL

The experiment was conducted at the Bangabandhu Sheikh Mujibur Rahman Agricultural University during the period of November 2014 to April 2015. The soil of the experimental field belongs to Salna series representing the Shallow Red Brown Terrace soil, which falls under Inceptisols order in Soil Taxonomy. The texture of soil is silty clay loam (Table 1), representing the agro-ecological zone (AEZ) Madhupur Tract (AEZ 28). Different physicochemical properties of soil sample collected from the experimental field were analyzed and were presented in Table 1. The collected sample of organic nitrogen sources used as cow dung, poultry litter and mustard oil cake were also analyzed and their analytical value were presented in Table 2.

\section{EXPERIENTIAL DESIGN AND TREATMENTS}

The experiment was laid out in a randomized complete block design with three replications. Four levels of inorganic N $\left(140,160,180 \mathrm{~kg} \mathrm{~N} \mathrm{ha}^{-1}\right.$ from USG and 180 $\mathrm{kg} \mathrm{N} \mathrm{ha}^{-1}$ from $\mathrm{PU}$ ) and two levels of three organic nitrogen sources (mustard oil cake (OC) 1 and $2 \mathrm{t} \mathrm{ha}^{-1}$, poultry manure (PM) 2 and $3 \mathrm{t} \mathrm{ha}^{-1}$ and cow dung (CD) 3 and $5 \mathrm{t}$ $\left.\mathrm{ha}^{-1}\right)$. These manures and fertilizers consisted 24 treatment combinations are presented in Table 3.

\section{APPLICATION METHOD OF MANURE AND FERTILIZER}

Cow dung, poultry manure and mustard oil cake were spread uniformly in the plots and incorporated into the soil by spading. Urea (USG and PU), triple super phosphate (TSP), muriate of potash (MoP), gypsum, boric acid, zinc oxide, and sodium molybdate were used as the source of N, P, K, S, B, Zn, and Mo, respectively. All fertilizers with $50 \%$ MoP except urea were applied as broadcast and incorporated into soil during final land preparation. PU was top-dressed in two equal splits at 15 and 35 days after planting (DAP) of broccoli seedlings as ring method around

TABLE 1. Physicochemical properties of soil of the experimental field

\begin{tabular}{lclc}
\hline \multicolumn{2}{c}{ Physical properties of soil } & \multicolumn{2}{c}{ Chemical properties of soil } \\
\hline Soil properties & Analytical value & Soil properties & Analytical value \\
\hline Particle size distribution & Sand (\%): 17.8 & Soil pH & 5.97 \\
& Silt (\%): 45.6 & Organic carbon (\%) & 0.96 \\
& Clay (\%): 36.6 & Total N $(\%)$ & 0.083 \\
Soil texture & Silty clay loam & Available P $(\mu \mathrm{g} / \mathrm{g})$ & 15.14 \\
Bulk density $(\mathrm{g} / \mathrm{cc})$ & 1.34 & Exchangeable K (meq/100 g & 0.298 \\
& & soil) & 11.878 \\
Particle density $(\mathrm{g} / \mathrm{cc})$ & 2.61 & Available S $(\mu \mathrm{g} / \mathrm{g})$ & 0.182 \\
Porosity $(\%)$ & 47.47 & Available B $(\mu \mathrm{g} / \mathrm{g})$ & 12.67 \\
Field capacity $(\%)$ & 28.67 & CEC (meq/100 g soil) & \\
\hline
\end{tabular}


TABLE 2. Nutrient status of cow dung, poultry manure and mustard oil cake

\begin{tabular}{lccccc}
\hline Sample & \multicolumn{5}{c}{ Nutrient content (oven dry basis) } \\
\cline { 2 - 6 } & Moisture (\%) & $\mathrm{N}(\%)$ & $\mathrm{P}(\%)$ & $\mathrm{K}(\%)$ & 0.68 \\
\hline Cow dung & 41.53 & 1.35 & 1.01 & 0.82 & 0.24 \\
Poultry litter & 48.57 & 1.72 & 1.29 & 0.71 & 0.38 \\
Mustard oil cake & 18.88 & 5.32 & 0.83 & 0.66 \\
\hline
\end{tabular}

TABLE 3. The treatment combinations were adjusted as IPNS basis from NPKS fertilizers

\begin{tabular}{|c|c|c|}
\hline Treat & Treatment combinations & Calculated fertilizer doses as IPNS basis \\
\hline $\mathrm{T}_{1}$ & 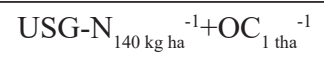 & 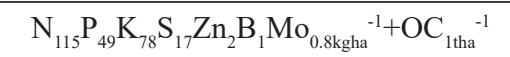 \\
\hline $\mathrm{T}_{2}$ & USG-N ${ }_{140 \mathrm{~kg} \mathrm{ha}^{-1}}+\mathrm{OC}_{2 \text { tha }}-1$ & $\mathrm{~N}_{89} \mathrm{P}_{45} \mathrm{~K}_{73} \mathrm{~S}_{13} \mathrm{Zn}_{2} \mathrm{~B}_{1} \mathrm{Mo}_{0.8 \mathrm{kgha}}{ }^{-1}+\mathrm{OC}_{2 \text { tha }}{ }^{-1}$ \\
\hline $\mathrm{T}_{3}$ & USG-N ${ }_{140 \mathrm{~kg} \mathrm{ha}^{-1}}+\mathrm{PM}_{2 \text { tha }}{ }^{-1}$ & $\mathrm{~N}_{117} \mathrm{P}_{32} \mathrm{~K}_{69} \mathrm{~S}_{16} \mathrm{Zn}_{2} \mathrm{~B}_{1} \mathrm{Mo}_{0.8 \mathrm{kgha}}{ }^{-1}+\mathrm{PM}_{2 \text { tha }}{ }^{-1}$ \\
\hline $\mathrm{T}_{4}$ & 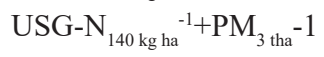 & $\mathrm{N}_{106} \mathrm{P}_{22} \mathrm{~K}_{62} \mathrm{~S}_{14} \mathrm{Zn}_{2} \mathrm{~B}_{1} \mathrm{Mo}_{0.8 \mathrm{kgha}}{ }^{-1}+\mathrm{PM}_{3 \text { tha }}{ }^{-1}$ \\
\hline $\mathrm{T}_{5}$ & 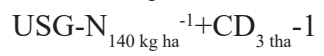 & $\mathrm{N}_{127} \mathrm{P}_{49} \mathrm{~K}_{68} \mathrm{~S}_{16} \mathrm{Zn}_{2} \mathrm{~B}_{1} \mathrm{Mo}_{0.8 \mathrm{kgha}}{ }^{-1}+\mathrm{CD}_{3 \text { tha }}{ }^{-1}$ \\
\hline $\mathrm{T}_{6}$ & 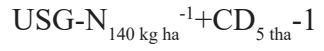 & $\mathrm{N}_{118} \mathrm{P}_{46} \mathrm{~K}_{58} \mathrm{~S}_{14} \mathrm{Zn}_{2} \mathrm{~B}_{1} \mathrm{Mo}_{0.8 \mathrm{kgha}}{ }^{-1}+\mathrm{CD}_{2 \text { tha }}^{-1}$ \\
\hline $\mathrm{T}_{7}$ & USG-N ${ }_{160 \mathrm{kgha}}{ }^{-1}+\mathrm{OC}_{1 \text { tha }}-1$ & $\mathrm{~N}_{135} \mathrm{P}_{49} \mathrm{~K}_{78} \mathrm{~S}_{17} \mathrm{Zn}_{2} \mathrm{~B}_{1} \mathrm{Mo}_{0.8 \mathrm{kgha}}{ }^{-1}+\mathrm{OC}_{1 \text { tha }}{ }^{-1}$ \\
\hline $\mathrm{T}_{8}$ & USG-N ${ }_{160 \mathrm{~kg} \mathrm{ha}^{-1}}+\mathrm{OC}_{2 \text { tha }}{ }^{-1}$ & $\mathrm{~N}_{109} \mathrm{P}_{45} \mathrm{~K}_{73} \mathrm{~S}_{13} \mathrm{Zn}_{2} \mathrm{~B}_{1} \mathrm{Mo}_{0.8 \mathrm{kgha}}{ }^{-1}+\mathrm{OC}_{2 \text { tha }}{ }^{-1}$ \\
\hline $\mathrm{T}_{9}$ & USG-N ${ }_{160 \mathrm{~kg} \mathrm{ha}^{-1}}+\mathrm{PM}_{2 \text { tha }}{ }^{-1}$ & $\mathrm{~N}_{137} \mathrm{P}_{32} \mathrm{~K}_{69} \mathrm{~S}_{16} \mathrm{Zn}_{2} \mathrm{~B}_{1} \mathrm{Mo}_{0.8 \mathrm{kgha}}{ }^{-1}+\mathrm{PM}_{2 \text { tha }}{ }^{-1}$ \\
\hline $\mathrm{T}_{10}$ & 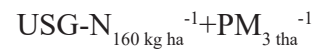 & $\mathrm{N}_{126} \mathrm{P}_{22} \mathrm{~K}_{62} \mathrm{~S}_{14} \mathrm{Zn}_{2} \mathrm{~B}_{1} \mathrm{Mo}_{0.8 \mathrm{kgha}}{ }^{-1}+\mathrm{PM}_{3 \mathrm{tha}}{ }^{-1}$ \\
\hline $\mathrm{T}_{11}$ & 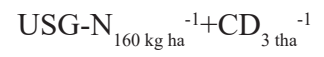 & $\mathrm{N}_{147} \mathrm{P}_{49} \mathrm{~K}_{68} \mathrm{~S}_{16} \mathrm{Zn}_{2} \mathrm{~B}_{1} \mathrm{Mo}_{0.8 \mathrm{kgha}}{ }^{-1}+\mathrm{CD}_{3 \text { tha }}{ }^{-1}$ \\
\hline $\mathrm{T}_{12}$ & USG-N ${ }_{160 \mathrm{~kg} \mathrm{ha}^{-1}}+\mathrm{CD}_{5 \text { tha }}{ }^{-1}$ & $\mathrm{~N}_{138} \mathrm{P}_{46} \mathrm{~K}_{58} \mathrm{~S}_{14} \mathrm{Zn}_{2} \mathrm{~B}_{1} \mathrm{Mo}_{0.8 \mathrm{kgha}}{ }^{-1}+\mathrm{CD}_{5 \text { tha }}^{-1}$ \\
\hline $\mathrm{T}_{13}$ & 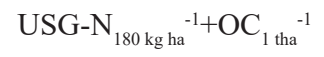 & $\mathrm{N}_{155} \mathrm{P}_{49} \mathrm{~K}_{78} \mathrm{~S}_{17} \mathrm{Zn}_{2} \mathrm{~B}_{1} \mathrm{Mo}_{0.8 \mathrm{kgha}}{ }^{-1}+\mathrm{OC}_{1 \text { tha }}{ }^{-1}$ \\
\hline $\mathrm{T}_{14}$ & 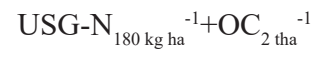 & $\mathrm{N}_{129} \mathrm{P}_{45} \mathrm{~K}_{73} \mathrm{~S}_{13} \mathrm{Zn}_{2} \mathrm{~B}_{1} \mathrm{Mo}_{0.8 \mathrm{kgha}}{ }^{-1}+\mathrm{OC}_{2 \text { tha }}{ }^{-1}$ \\
\hline $\mathrm{T}_{15}$ & USG- $\mathrm{N}_{180 \mathrm{~kg} \mathrm{ha}^{-1}}+\mathrm{PM}_{2 \text { tha }}{ }^{-1}$ & $\mathrm{~N}_{157} \mathrm{P}_{32} \mathrm{~K}_{69} \mathrm{~S}_{16} \mathrm{Zn}_{2} \mathrm{~B}_{1} \mathrm{Mo}_{0.8 \mathrm{kgha}}{ }^{-1}+\mathrm{PM}_{2 \mathrm{tha}}{ }^{-1}$ \\
\hline $\mathrm{T}_{16}$ & USG- $\mathrm{N}_{180 \mathrm{~kg} \mathrm{ha}}{ }^{-1}+\mathrm{PM}_{3 \text { tha }}{ }^{-1}$ & $\mathrm{~N}_{146} \mathrm{P}_{22} \mathrm{~K}_{62} \mathrm{~S}_{14} \mathrm{Zn}_{2} \mathrm{~B}_{1} \mathrm{Mo}_{0.8 \mathrm{kgha}}{ }^{-1}+\mathrm{PM}_{3 \text { tha }}^{-1}$ \\
\hline $\mathrm{T}_{17}$ & USG-N ${ }_{180 \mathrm{~kg} \mathrm{ha}^{-1}}+\mathrm{CD}_{3 \text { tha }}{ }^{-1}$ & $\mathrm{~N}_{167} \mathrm{P}_{49} \mathrm{~K}_{68} \mathrm{~S}_{16} \mathrm{Zn}_{2} \mathrm{~B}_{1} \mathrm{Mo}_{0.8 \mathrm{kgha}}{ }^{-1}+\mathrm{CD}_{3 \text { tha }}{ }^{-1}$ \\
\hline $\mathrm{T}_{18}$ & USG- $\mathrm{N}_{180 \mathrm{~kg} \mathrm{ha}}{ }^{-1}+\mathrm{CD}_{5 \text { tha }}{ }^{-1}$ & $\mathrm{~N}_{158} \mathrm{P}_{46} \mathrm{~K}_{58} \mathrm{~S}_{14} \mathrm{Zn}_{2} \mathrm{~B}_{1} \mathrm{Mo}_{0.8 \mathrm{kgha}}{ }^{-1}+\mathrm{CD}_{5 \text { tha }}{ }^{-1}$ \\
\hline $\mathrm{T}_{19}$ & 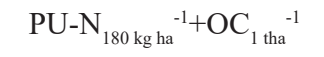 & $\mathrm{N}_{155} \mathrm{P}_{49} \mathrm{~K}_{78} \mathrm{~S}_{17} \mathrm{Zn}_{2} \mathrm{~B}_{1} \mathrm{Mo}_{0.8 \mathrm{kgha}}{ }^{-1}+\mathrm{OC}_{1 \text { tha }}^{-1}$ \\
\hline $\mathrm{T}_{20}$ & PU-N ${ }_{180 \mathrm{~kg} \mathrm{ha}}{ }^{-1}+\mathrm{OC}_{2 \text { tha }}{ }^{-1}$ & $\mathrm{~N}_{129} \mathrm{P}_{45} \mathrm{~K}_{73} \mathrm{~S}_{13} \mathrm{Zn}_{2} \mathrm{~B}_{1} \mathrm{Mo}_{0.8 \mathrm{kgha}}^{-{ }^{-1}}+\mathrm{OC}_{2 \text { tha }}^{-1}$ \\
\hline $\mathrm{T}_{21}$ & PU-N ${ }_{180 \mathrm{~kg} \mathrm{ha}}{ }^{-1}+\mathrm{PM}_{2 \text { tha }}{ }^{-1}$ & $\mathrm{~N}_{157} \mathrm{P}_{32} \mathrm{~K}_{69} \mathrm{~S}_{16} \mathrm{Zn}_{2} \mathrm{~B}_{1} \mathrm{Mo}_{0.8 \mathrm{kgha}}{ }^{-1}+\mathrm{PM}_{2 \mathrm{tha}}{ }^{-1}$ \\
\hline $\mathrm{T}_{22}$ & 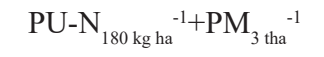 & $\mathrm{N}_{146} \mathrm{P}_{22} \mathrm{~K}_{62} \mathrm{~S}_{14} \mathrm{Zn}_{2} \mathrm{~B}_{1} \mathrm{Mo}_{0.8 \mathrm{kgha}}{ }^{-1}+\mathrm{PM}_{3 \text { tha }}{ }^{-1}$ \\
\hline $\mathrm{T}_{23}$ & PU-N ${ }_{180 \mathrm{~kg} \mathrm{ha}^{-1}}+\mathrm{CD}_{3 \text { tha }}{ }^{-1}$ & $\mathrm{~N}_{167} \mathrm{P}_{49} \mathrm{~K}_{68} \mathrm{~S}_{16} \mathrm{Zn}_{2} \mathrm{~B}_{1} \mathrm{Mo}_{0.8 \mathrm{kgha}}{ }^{-1}+\mathrm{CD}_{3 \text { tha }}{ }^{-1}$ \\
\hline $\mathrm{T}_{24}$ & PU-N ${ }_{180 \mathrm{~kg} \mathrm{ha}}{ }^{-1}+\mathrm{CD}_{5 \text { tha }}{ }^{-1}$ & 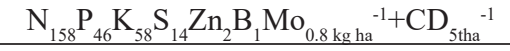 \\
\hline
\end{tabular}

the plant and properly mixed with soil. The rest $50 \% \mathrm{MoP}$ was top-dressed at 15 DAP. USG was placed at 15 DAP in ring method at a depth of 7-8 cm in soil and 9-10 cm apart from plant base followed by irrigation (depending on soil moisture). Mustard oil cake was decomposed in water for 7 days, applied in the plot soil and mixed well one week before planting. Similarly, decomposed cow dung and poultry manure were applied in soil and mixed well one week prior to planting. Nutrients $\mathrm{N}, \mathrm{P}, \mathrm{K}$, and $\mathrm{S}$ from organic materials were calculated according to Fertilizer Recommendation Guide (BARC 2012).

\section{CULTIVATION PRACTICES}

Twenty-five day-old seedlings of broccoli (Brassica oleracea var. Italica L.) variety Premium Crop was transplanted on $20^{\text {th }}$ November 2014. Seedlings were transplanted in lines maintaining row to row and plant to plant distance of $0.60 \mathrm{~m}$ and $0.45 \mathrm{~m}$, respectively.

\section{INTERCULTURAL OPERATION}

After transplanting, regular watering was done by water can and hosepipe up to stand establishment. In later stages, regular irrigation was given at an interval of 7 days and after each top dressing (depending on soil moisture status). Moreover, necessary irrigation was ensured up to harvesting of lateral heads. Two times weeding were done just before first and second top dressing.

\section{DATA COLLECTION}

Average number of leaves per plant was counted by selecting five plants from each treatment at 10 days' 
interval starting from 10 DAP and similarly plant height was measured. Well-developed broccoli heads from each treatment were harvested at an interval of 3-5 days throughout the harvest season (February to April 2015). The crop was harvested when the head or inflorescence was at commercial maturity, just started to swell but before opening the flower bud. Three randomly selected plants including the head and roots were harvested very carefully with the help of a shovel and data on total weight, fresh root and shoot weight, leaf number, head weight and yield data were recorded soon after harvest. Subsequently its dry weights were determined followed by drying in an oven to a constant weight at $75^{\circ} \mathrm{C}$ for $72 \mathrm{~h}$ according to Tandon (1995). Before harvest, head diameter and after harvest head length was measured using centi-meter scale. The weight of individual head was taken including the stalk with three young leaves attached with head as the marketable portion of the plant was considered to the extent of about $15 \mathrm{~cm}$ from the top of the inflorescence along the stem according to Liu et al. (1993). After harvest of main head, 10 plants were selected for recording data on lateral head formation. Lateral head data were recorded when the head was attained to harvesting stage. Harvest index was measured for the crop that can be expressed as the ratio of yield to total above-ground biomass. In this experiment harvest index was calculated following the formulae:

Harvest index $=\frac{\text { Commercial yield (Head) }}{\text { Total aboveground biomass yield }} \times 100$

\section{ECONOMIC EVALUATION}

Economic parameters of the experiment were also recorded for economic analysis and evaluation. Economic evaluation of different fertilizer combinations was done through partial budgeting and dominance analysis followed by marginal analysis of the cost-undominated treatments as suggested by Perrin et al. (1979). Gross return and total variable costs were calculated considering the following rate of costs of the materials: Seed=Tk.250/10g; Urea@ Tk14.00 kg-1, USG@Tk15.00 kg-11,TSP@Tk22.00 kg 1, MoP@Tk20 kg-1, Gypsum@Tk $7.00 \mathrm{~kg}^{-1}$, Cow dung @ Tk.1500.00 Ton ${ }^{-1}$, poultry manure@ @. Tk.2000.00 Ton 1, Borax@Tk15.00 kg-1, ZnO and Sodium molybdate@ Tk $180.00 \mathrm{~kg}^{-1}$. Broccoli market price@ Tk $30.00 \mathrm{~kg}^{-1}$. Benefit cost ratio (BCR) and marginal rate of return (MRR) was calculated using the following formulae:

$$
\begin{gathered}
\text { BCR }=\frac{\text { Gross return }\left(\mathrm{Tk} \cdot \mathrm{ha}^{-1}\right)}{\text { Total cost of cultivation }\left(\mathrm{Tk} \cdot \mathrm{ha}^{-1}\right)} \\
\operatorname{MRR}(\%)=\frac{\text { Marginal Gross Margin }\left(\mathrm{Tk} . \mathrm{ha}^{-1}\right) \times 100}{\text { Marginal Variable Cost }\left(\mathrm{Tk} \cdot \mathrm{ha}^{-1}\right)}
\end{gathered}
$$

\section{STATISTICAL ANALYSIS}

The analysis of variance (ANOVA) for different crop parameters and dry matter was done following the F test.
When the F was significant at the $p<0.05$ level, the means were separated by DMRT test (Steel \& Torii 1980).

\section{RESULTS AND DISCUSSION}

\section{PLANT HEIGHT}

Plant height is a central part of plant ecological strategy which also indicated the growth pattern of a crop. The plant height was significantly influenced by the different form of urea-N and different form of organic manure. At 50 DAP, the highest plant height $(64.1 \mathrm{~cm})$ was found in $\mathrm{USG}_{180 \mathrm{~kg}}$ $+\mathrm{OC}_{2 \text { tha }}$ followed by $\mathrm{PU}_{180 \mathrm{~kg}}+\mathrm{OC}_{2 \text { tha }}$ and $\mathrm{USG}_{160 \mathrm{~kg}}+\mathrm{OC}_{2}$ tha. The lowest plant height $(51.6 \mathrm{~cm})$ was noted in $\mathrm{USG}_{140 \mathrm{~kg}}$ $+\mathrm{PM}_{2 \text { tha }}$. At 70 DAP, $\mathrm{USG}_{180 \mathrm{~kg}}+\mathrm{OC}_{2 \text { tha }}$ also showed the highest plant, which was followed by $\mathrm{USG}_{160 \mathrm{~kg}}+\mathrm{OC}_{2 \text { tha }}$ and $\mathrm{PU}_{180 \mathrm{~kg}}+\mathrm{OC}_{2 \text { tha }}$ (Table 3). It was observed that the plant height was increased with the increase in nitrogen doses. It was also found that urea super granules (USG) showed better performance than the prilled urea (PU). The highest plant height might be due to rapid cell development and cell elongation by the higher doses of $\mathrm{N}$, maximum and continuous supply of available $\mathrm{N}$ from USG and higher $\mathrm{N}$ uptake efficiency that induced higher growth as well as plant height. These results are also at par with findings of Rakesh et al. (2006) who reported that organic manure plus mineral fertilizer increase vegetative growth including plant height of broccoli.

\section{FRESH ROOT AND SHOOT WEIGHT}

The fresh root and shoot weight were significantly influenced by the different treatment combination. The highest fresh root weight $\left(61.1 \mathrm{~g} \mathrm{plant}^{-1}\right)$ was found in $\mathrm{USG}_{180 \mathrm{~kg}}+\mathrm{PM}_{3 \text { tha }}$ which was significantly higher than the other treatment combinations (Table 4). The minimum fresh root weight (41.6 $\left.\mathrm{g} \mathrm{plant}^{-1}\right)$ was recorded in $\mathrm{PU}_{180 \mathrm{~kg}}$ $+\mathrm{OC}_{1 \text { tha }}$ which was statistically identical to $\mathrm{USG}_{140 \mathrm{~kg}}+\mathrm{CD}_{5}$ tha

The highest fresh root weight was observed in $\mathrm{USG}_{180 \mathrm{~kg}}$ $+\mathrm{PM}_{3 \text { tha }}$ and this might be due to higher root expansion with lower $\mathrm{N}$ and $\mathrm{P}$ supply to the crop as poultry liter was a rich but slow release source of $\mathrm{N}$ as well as $\mathrm{P}$. The highest fresh shoot weight $\left(1611 \mathrm{~g} \mathrm{plant}^{-1}\right)$ was found in $\mathrm{USG}_{180 \mathrm{~kg}}$ $+\mathrm{OC}_{2 \text { tha }}$ followed by $\mathrm{USG}_{160 \mathrm{~kg}}+\mathrm{OC}_{2 \text { tha }}\left(1568 \mathrm{~g} \mathrm{plant}^{-1}\right)$ (Table 4). The minimum fresh soot weight (1203 g plant $\left.^{-1}\right)$ was noted in $\mathrm{USG}_{140 \mathrm{~kg}}+\mathrm{PM}_{2 \text { tha }}$. The highest fresh shoot weight might be due to higher vegetative growth with higher $\mathrm{N}$ supply to the crop. The fresh weight presented in Table 5 clearly indicated that USG-N and the organic manures as a source of organic $\mathrm{N}$ play a vital role to boost the fresh weight of root and shoot. Similar results were also observed by Rakesh et al. (2006) where organic manure along with mineral fertilizer increase vegetative growth as well as fresh shoot weight of broccoli.

\section{DRY ROOT AND SHOOT WEIGHT}

Dry root weight was significantly influenced by different treatment combination. USG-N $\mathrm{N}_{180 \mathrm{~kg} / \mathrm{ha}}+\mathrm{PM}_{3 \text { tha }}$ showed the 
highest dry root weight $\left(14.4 \mathrm{~g} \mathrm{plant}^{-1}\right)$, which was significantly higher than the other treatment followed by USG-N $_{160 \mathrm{~kg} / \mathrm{ha}}+\mathrm{OC}_{2 \mathrm{tha}}$. The lowest root dry weight (10.61 g

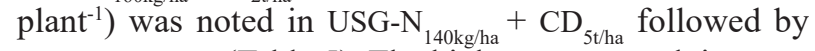
USG-N $\mathrm{N}_{180}+\mathrm{OC}_{1}$ (Table 5). The higher root growth in USG$\mathrm{N}_{180 \mathrm{~kg} / \mathrm{ha}}+\mathrm{PM}_{3 \text { th ha }}$ and this might be due to higher $\mathrm{P}$ and $\mathrm{N}$ supply from poultry and USG, respectively, to the crop. Dry shoot weight was also significantly influenced by the different treatment combination. The highest dry shoot weight (207.8 g plant $^{-1}$ ) was recorded in USG-N $\mathrm{N}_{180 \mathrm{~kg} / \mathrm{ha}}+\mathrm{OC}_{2 \mathrm{t}}$ ha followed by USG-N ${ }_{160 \mathrm{~kg} / \mathrm{ha}}+\mathrm{OC}_{2}\left(202.3 \mathrm{~g} \mathrm{plant}^{-1}\right)$. The lowest dry shoot weight $\left(155.2 \mathrm{~g}\right.$ ) was found in USG-N $\mathrm{N}_{140 \mathrm{~kg} /}$ ${ }_{\text {ha }}+\mathrm{PM}_{2 \mathrm{tha}}$ (Table 6). The higher dry matter production with higher vegetative growth through higher $\mathrm{N}$ supply with the complements of organic manure (oil cake) and chemical fertilizer (USG). Basel et al. (2008) reported that fresh and dry weights of broccoli shoots were significantly influenced by the application of different doses of organic manure and chemical fertilizers which are in agreement with the findings of our results.

\section{HEAD LENGTH AND HEAD DIAMETER}

Head length was not significantly influenced by the organic manure and chemical fertilizers. The highest head length $(14.50 \mathrm{~cm})$ was found in USG-N $\mathrm{N}_{180 \mathrm{~kg} / \mathrm{ha}}+\mathrm{PM}_{2 \mathrm{tha}}$ which was closely followed by PU-N $\mathrm{N}_{180 \mathrm{~kg} / \mathrm{ha}}+\mathrm{PM}_{2 \text { tha }}$ and the lowest was noted in PU-N ${ }_{180 \mathrm{~kg} / \mathrm{ha}}+\mathrm{OC}_{2 \mathrm{tha}}$ (Table 5).
Head diameter was significantly influenced by the different treatment combinations. Treatments USG-N ${ }_{160 \mathrm{~kg} /}$ ha $+\mathrm{PM}_{3 \text { tha }}$ and USG-N $\mathrm{N}_{160 \mathrm{~kg} / \mathrm{ha}}+\mathrm{OC}_{2 \text { tha }}$ showed the highest head diameter $(18.2 \mathrm{~cm})$ followed by USG-N $\mathrm{N}_{180 \mathrm{~kg} / \mathrm{ha}}+\mathrm{OC}_{2 \mathrm{tha}}$ and USG- $\mathrm{N}_{160 \mathrm{~kg} / \mathrm{ha}}+\mathrm{CD}_{5 \text { tha }}$ (Table 5). The minimum head diameter $(13.9 \mathrm{~cm})$ was recorded in USG-N ${ }_{140 \mathrm{~kg} / \mathrm{ha}}+\mathrm{OC}_{1 \mathrm{t} / \mathrm{ha}}$. The continuous supply of $\mathrm{N}$ from USG and organic manure helped to increase or spread head. This finding was supported by Yoldas et al. (2008) where N rates significantly increased the diameter in broccoli head as compared to control. This study is in line with Basel et al. (2008) in broccoli production. Same result was also reported by Bahadur et al. (2003) in broccoli.

\section{HEAD WEIGHT AND HEAD YIELD}

The head weight $\left(\mathrm{g}\right.$ plant $\left.{ }^{-1}\right)$ was significantly variable among the treatment combinations. The highest head weight (398.3 g plant $^{-1}$ ) was found in USG-N ${ }_{160 \mathrm{~kg} / \mathrm{ha}}+\mathrm{OC}_{2 \mathrm{tha}}$, which was statistically similar with USG-N $\mathrm{N}_{180 \mathrm{~kg} / \mathrm{ha}}+\mathrm{OC}_{2 \text { tha }}$ but different from rest of the treatments (Table 6). The minimum head weight was noted in USG-N $\mathrm{N}_{140 \mathrm{~kg} / \mathrm{ha}}+\mathrm{CD}_{3 \text { tha }}$ followed by USG-N $\mathrm{N}_{140 \mathrm{~kg} / \mathrm{ha}}+\mathrm{PM}_{2 \mathrm{th} \text { a }}$. The higher head weight in USG-N $\mathrm{N}_{160 \mathrm{~kg} / \mathrm{ha}}+\mathrm{OC}_{2 \text { tha }}$ might be due to the fact that USG in combination with oil cake helps for better root proliferation, which facilitates more uptakes of nutrients and water, higher leaf number as well as more leaf area for effective photosynthesis that enhanced food accumulation.

TABLE 4. Integrated effect of different levels of inorganic and organic sources of $\mathrm{N}$ on plant height at different days after planting (DAP)

\begin{tabular}{|c|c|c|c|c|c|}
\hline Treatment & 30 DAP $(\mathrm{cm})$ & 40 DAP $(\mathrm{cm})$ & 50 DAP $(\mathrm{cm})$ & 60 DAP $(\mathrm{cm})$ & 70 DAP $(\mathrm{cm})$ \\
\hline $\mathrm{USG} \mathrm{N}_{140 \mathrm{~kg} / \mathrm{ha}}+\mathrm{OC}_{1 \text { tha }}$ & $34.85 \mathrm{abc}$ & 48.75 a-f & 60.03 a-d & $66.30 \mathrm{~b}-\mathrm{d}$ & 66.53 a-e \\
\hline 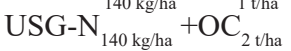 & 35.67 a & 51.77 a-d & 61.79 a-c & $67.11 \mathrm{a}-\mathrm{c}$ & 67.76 a-d \\
\hline $\mathrm{USG} \mathrm{N}_{140 \mathrm{~kg} / \mathrm{ha}}^{140 \mathrm{~kg} / \mathrm{ha}}+\mathrm{PM}_{2 \mathrm{t} / \mathrm{ha}}^{2 \mathrm{t} / \mathrm{ha}}$ & 29.30 d-f & $41.59 \mathrm{f}$ & $51.65 \mathrm{~g}$ & $61.67 \mathrm{~d}-\mathrm{f}$ & $61.46 \mathrm{gh}$ \\
\hline USG-N $_{140 \mathrm{~kg} / \mathrm{ha}}+\mathrm{PM}_{3 \mathrm{t} \text { tha }}$ & 34.29 a-d & $47.47 \quad b-f$ & $55.94 \mathrm{c}-\mathrm{g}$ & 64.30 b-f & 64.49 d-g \\
\hline $\mathrm{USG} \mathrm{N}_{140 \mathrm{~kg} / \mathrm{ha}}+\mathrm{CD}_{3 \mathrm{t} / \mathrm{ha}}$ & 32.00 a-f & $41.92 \mathrm{f}$ & $53.10 \mathrm{fg}$ & $62.60 \mathrm{c}-\mathrm{f}$ & $62.72 \mathrm{f}-\mathrm{h}$ \\
\hline $\mathrm{USG}^{-N_{140}^{140 \mathrm{~kg} / \mathrm{ha}}}+\mathrm{CD}_{5 \mathrm{t} / \mathrm{ha}}^{3 \text { tha }}$ & 32.55 a-e & $45.23 \mathrm{c}-\mathrm{f}$ & $53.37 \mathrm{e}-\mathrm{g}$ & $62.63 \mathrm{c}-\mathrm{f}$ & 63.21 e-h \\
\hline $\mathrm{USG} \mathrm{N}_{160 \mathrm{~kg} / \mathrm{ha}}+\mathrm{OC}_{1 \mathrm{t} / \mathrm{ha}}$ & $35.37 \mathrm{ab}$ & 50.99 a-d & 60.70 a-d & $64.63 \mathrm{~b}-\mathrm{f}$ & 65.48 b-f \\
\hline USG-N $_{160 \mathrm{~kg} / \mathrm{ha}}+\mathrm{OC}_{2 \mathrm{t} / \mathrm{ha}}$ & $36.09 \mathrm{a}$ & $52.79 \mathrm{ab}$ & $62.47 \mathrm{ab}$ & $68.96 \mathrm{ab}$ & $68.92 \mathrm{ab}$ \\
\hline USG-N $_{160 \mathrm{~kg} / \mathrm{ha}}+\mathrm{PM}_{2 \mathrm{t} \text { /ha }}$ & 34.20 a-d & $44.56 \mathrm{~d}-\mathrm{f}$ & 56.59 b-g & $66.43 \mathrm{~b}-\mathrm{d}$ & 66.39 a-e \\
\hline 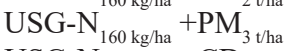 & 34.37 a-d & 46.45 b-f & 57.03 b-g & $67.77 \mathrm{ab}$ & $67.19 \mathrm{a}-\mathrm{d}$ \\
\hline USG-N $_{160 \mathrm{~kg} / \mathrm{ha}}+\mathrm{CD}_{3 \mathrm{t} / \mathrm{ha}}$ & 28.44 ef & 43.43 ef & 54.91 d-g & 61.17 ef & $61.30 \mathrm{gh}$ \\
\hline USG-N $_{160 \mathrm{~kg} / \mathrm{ha}}+\mathrm{CD}_{5 \mathrm{t} / \mathrm{ha}}$ & $29.75 c-f$ & $45.33 \mathrm{c}-\mathrm{f}$ & $56.10 \mathrm{c}-\mathrm{g}$ & 64.52 b-f & 65.64 b-f \\
\hline USG-N $_{180 \mathrm{~kg} / \mathrm{ha}}+\mathrm{OC}_{1 \mathrm{t} / \mathrm{ha}}$ & 31.98 a-f & 48.63 a-f & 59.77 a-d & 67.40 a-c & $66.17 \mathrm{~b}-\mathrm{f}$ \\
\hline $\mathrm{USG} \mathrm{N}_{180 \mathrm{~kg} / \mathrm{ha}}+\mathrm{OC}_{2 \mathrm{t} / \mathrm{ha}}$ & $36.27 \mathrm{a}$ & $52.31 \mathrm{a}-\mathrm{c}$ & $64.10 \mathrm{a}$ & $71.65 \mathrm{a}$ & $69.61 \mathrm{a}$ \\
\hline USG-N $_{180 \mathrm{~kg} / \mathrm{ha}}+\mathrm{PM}_{2 \text { tha }}$ & $30.01 \mathrm{c}-\mathrm{f}$ & 47.89 b-f & 60.62 a-d & 65.00 b-f & $65.02 \mathrm{~d}-\mathrm{f}$ \\
\hline USG-N $_{180 \mathrm{~kg} / \mathrm{ha}}+\mathrm{PM}_{3 \mathrm{t} \text { tha }}$ & 31.87 a-f & 49.70 a-e & $61.07 \mathrm{a}-\mathrm{c}$ & $68.52 \mathrm{ab}$ & $65.66 \mathrm{~b}-\mathrm{f}$ \\
\hline $\mathrm{USG} \mathrm{N}_{180 \mathrm{~kg} / \mathrm{ha}}+\mathrm{CD}_{3 \mathrm{t} / \mathrm{ha}}$ & $26.90 \mathrm{f}$ & $42.13 \mathrm{f}$ & 56.62 b-g & 66.07 b-e & $65.08 \mathrm{c}-\mathrm{f}$ \\
\hline USG-N $_{180 \mathrm{~kg} / \mathrm{ha}}+\mathrm{CD}_{5 \mathrm{t} / \mathrm{ha}}$ & $29.81 \quad c-f$ & $46.05 \mathrm{~b}-\mathrm{f}$ & 58.69 a-f & $66.68 \mathrm{~b}-\mathrm{d}$ & 65.69 b-f \\
\hline PU-N ${ }_{180 \mathrm{~kg} / \mathrm{ha}}+\mathrm{OC}_{1 \mathrm{t} / \mathrm{ha}}$ & 31.91 a-f & 51.45 a-d & 61.17 a-c & 65.98 b-e & $65.02 \mathrm{~d}-\mathrm{f}$ \\
\hline $\mathrm{PU}-\mathrm{N}_{180 \mathrm{~kg} / \mathrm{ha}}^{180 \mathrm{kga}}+\mathrm{OC}_{2 \text { tha }}$ & $36.97 \mathrm{a}$ & $55.63 \mathrm{a}$ & $63.00 \mathrm{a}$ & $68.69 \mathrm{ab}$ & $68.56 \mathrm{a}-\mathrm{c}$ \\
\hline PU-N $180 \mathrm{~kg} / \mathrm{ha}=\mathrm{PM}_{2 \text { tha }}$ & 30.23 b-f & 46.37 b-f & $55.97 \mathrm{c}-\mathrm{g}$ & 64.17 b-f & 63.63 e-h \\
\hline PU-N ${ }_{180 \mathrm{~kg} / \mathrm{ha}}+\mathrm{PM}_{3 \text { tha }}$ & 34.21 a-d & $51.93 \mathrm{a}-\mathrm{c}$ & 59.18 a-e & 64.83 b-f & 65.77 b-f \\
\hline $\mathrm{PU}-\mathrm{N}_{180 \mathrm{~kg} / \mathrm{ha}}+\mathrm{CD}_{3 \mathrm{t} / \mathrm{ha}}$ & 28.95 ef & 46.77 b-f & 53.73 e-g & $60.02 \mathrm{f}$ & $60.53 \mathrm{~h}$ \\
\hline PU-N ${ }_{180 \mathrm{~kg} / \mathrm{ha}}+\mathrm{CD}_{5 \mathrm{t} / \mathrm{ha}}$ & 32.29 a-e & 50.93 a-d & 60.43 a-d & 65.27 b-e & $64.92 \mathrm{~d}-\mathrm{f}$ \\
\hline $\mathrm{CV}(\%)$ & 8.24 & 7.67 & 5.14 & 3.93 & 2.74 \\
\hline $\mathrm{SE}( \pm 0.05)$ & 1.542 & 2.122 & 1.728 & 1.488 & 1.032 \\
\hline
\end{tabular}

Figure(s) in a column having common letter(s) do not differ significantly at 5\% level of DMRT 
TABLE 5. Integrated effect of different levels of inorganic and organic sources of $\mathrm{N}$ on different plant parameters of broccoli

\begin{tabular}{|c|c|c|c|c|}
\hline Treatment & $\begin{array}{l}\text { Fresh root weight } \\
\qquad\left(\mathrm{g}_{\text {plant }}{ }^{-1}\right)\end{array}$ & $\begin{array}{l}\text { Fresh shoot weight } \\
\qquad\left(\mathrm{g} \mathrm{plant}^{-1}\right)\end{array}$ & $\begin{array}{l}\text { Dry root weight } \\
\left.\qquad\left(\mathrm{g}_{\text {plant }}\right)^{-1}\right)\end{array}$ & $\begin{array}{l}\text { Dry shoot weight } \\
\left(\text { g plant }^{-1}\right)\end{array}$ \\
\hline $\mathrm{USG} \mathrm{N}_{140 \mathrm{~kg} / \mathrm{ha}}+\mathrm{OC}_{1 \text { tha }}$ & 48.00 b-e & 1509 a-d & $10.69 \mathrm{fg}$ & 194.7 \\
\hline $\mathrm{USG} \mathrm{N}_{140 \mathrm{~kg} / \mathrm{ha}}^{140 \mathrm{~kg} / \mathrm{ha}}+\mathrm{OC}_{2 \mathrm{t} / \mathrm{ha}}^{1 \text { t/ha }}$ & 42.82 de & 1535 a-c & $12.13 \quad b-g$ & 193.7 a-e \\
\hline USG-N ${ }_{140 \mathrm{~kg} / \mathrm{ha}}^{14 \mathrm{gg} / \mathrm{Pa}}+\mathrm{PM}_{2 \text { tha }}^{2 \text { tha }}$ & $43.06 \mathrm{c}-\mathrm{e}$ & $1203 \mathrm{i}$ & $11.73 \quad \mathrm{c}-\mathrm{g}$ & $155.2 \mathrm{~h}$ \\
\hline $\mathrm{USG}-N_{140 \mathrm{~kg} / \mathrm{ha}}^{140 \mathrm{~kg} / \mathrm{ha}}+\mathrm{PM}_{3 \mathrm{t} / \mathrm{ha}}^{2 \text { tha }}$ & 45.68 b-e & $1309 \mathrm{f}-\mathrm{i}$ & 11.79 & $172.2 \mathrm{c}-\mathrm{h}$ \\
\hline USG-N ${ }_{140 \mathrm{~kg} / \mathrm{ha}}^{140 \mathrm{k} / \mathrm{ha}}+\mathrm{CD}_{3 \mathrm{t} / \mathrm{ha}}^{3}$ & 43.02 c-e & $1311 \mathrm{f}-\mathrm{i}$ & 11.26 d-g & 169.2 \\
\hline USG-N ${ }_{140 \mathrm{~kg} / \mathrm{ha}}^{140 \mathrm{k} / \mathrm{ha}}+\mathrm{CD}_{5 \mathrm{t} / \mathrm{ha}}$ & $41.67 \mathrm{e}$ & $1364 \mathrm{c}-\mathrm{i}$ & $10.60 \mathrm{~g}$ & 175.9 \\
\hline USG-N $N_{160 \mathrm{~kg} / \mathrm{ha}}^{14 \mathrm{gg} / \mathrm{Oa}}+\mathrm{OC}_{1 \text { tha }}^{\text {th/ha }}$ & 47.60 b-e & 1347 d-i & $12.78 \mathrm{~b}-\mathrm{d}$ & 173.8 \\
\hline $\mathrm{USG}^{-N_{160 \mathrm{~kg} / \mathrm{ha}}}+\mathrm{OC}_{2 \mathrm{t} / \mathrm{ha}}$ & $52.66 \mathrm{~b}$ & $1568 \mathrm{ab}$ & $13.71 \mathrm{ab}$ & 202.3 \\
\hline USG-N $_{160 \mathrm{~kg} / \mathrm{ha}}^{16 \mathrm{~kg} / \mathrm{aa}}+\mathrm{PM}_{2 \text { tha }}^{2 \text { tha }}$ & $52.37 \mathrm{bc}$ & $1248 \mathrm{hi}$ & 12.13 b-g & 161.0 \\
\hline USG-N $_{160 \mathrm{~kg} / \mathrm{ha}}^{10 \mathrm{~kg} / \mathrm{Pa}}+\mathrm{PM}_{3 \mathrm{t} / \mathrm{ha}}^{2 \text { tha }}$ & 48.00 b-e & $1373 \quad c-i$ & 12.52 b-e & 177.4 \\
\hline USG-N ${ }_{160 \mathrm{~kg} / \mathrm{ha}}^{10 \mathrm{~kg} / \mathrm{a}}+\mathrm{CD}_{3 \mathrm{t} / \mathrm{ha}}^{3 \mathrm{t} / \mathrm{a}}$ & 46.18 b-e & 1296 & 12.07 & 167.2 \\
\hline USG-N ${ }_{160 \mathrm{~kg} / \mathrm{ha}}^{160 \mathrm{~kg} / \mathrm{ha}}+\mathrm{CD}_{5 \text { t/ha }}^{3 \text { tha }}$ & 49.37 b-e & 1323 e-i & 12.37 b-f & 170.6 \\
\hline USG-N ${ }_{180 \mathrm{~kg} / \mathrm{ha}}^{16 \mathrm{~kg} / \mathrm{Oa}}+\mathrm{OC}_{1 \mathrm{t} \text { tha }}^{\text {th }}$ & 43.67 b-e & 1384 c-h & 11.52 & 178.5 \\
\hline 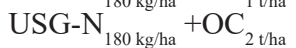 & 46.74 b-e & 1611 a & 11.71 & 207.8 a \\
\hline USG-N ${ }_{180 \mathrm{~kg} / \mathrm{ha}}^{18 \mathrm{~g} / \mathrm{aa}}+\mathrm{PM}_{2 \text { tha }}^{2 \mathrm{tha}}$ & $45.01 \mathrm{~b}-\mathrm{e}$ & 1477 a-f & 10.95 e-g & 190.5 a-f \\
\hline USG-N $_{180 \mathrm{~kg} / \mathrm{ha}}^{180 \mathrm{k} / \mathrm{ha}}+\mathrm{PM}_{3 \mathrm{t} / \mathrm{ha}}^{2 \mathrm{hat}}$ & $61.06 \mathrm{a}$ & 1502 & $14.37 \mathrm{a}$ & 198.1 \\
\hline USG-N ${ }_{180 \mathrm{~kg} / \mathrm{ha}}^{18 \mathrm{~kg} / \mathrm{C}}+\mathrm{CD}_{3 \mathrm{t} / \mathrm{ha}}^{3 \mathrm{tha}}$ & 46.99 b-e & 1378 & 11.24 d-g & 177.8 \\
\hline USG-N $_{180 \mathrm{~kg} / \mathrm{ha}}^{10 \mathrm{~kg} / \mathrm{Ca}}+\mathrm{CD}_{5 \mathrm{tha}}$ & $45.28 \mathrm{~b}-\mathrm{e}$ & $1430 \quad b-g$ & $11.93 \quad \mathrm{c}-\mathrm{g}$ & 184.5 \\
\hline PU-N ${ }_{180 \mathrm{~kg} / \mathrm{ha}}^{180 \mathrm{~kg}}+\mathrm{OC}_{1 \mathrm{t} / \mathrm{ha}}^{5 \mathrm{tha}}$ & $41.59 \mathrm{e}$ & 1278 g-i & $10.61 \mathrm{~g}$ & 164.9 \\
\hline PU-N ${ }_{180 \mathrm{~kg} / \mathrm{ha}}^{180 \mathrm{~kg} / \mathrm{ha}}+\mathrm{OC}_{2 \mathrm{t} / \mathrm{ha}}^{1 \text { t/ha }}$ & 51.08 b-d & 1384 c-h & $12.98 \quad \mathrm{a}-\mathrm{c}$ & 178.6 \\
\hline PU-N ${ }_{180 \mathrm{~kg} / \mathrm{ha}}^{180 \mathrm{kga}}+\mathrm{PM}_{2 \text { tha }}^{2 \text { t/tha }}$ & 50.89 b-e & 1319 f-i & $10.96 \mathrm{e}-\mathrm{g}$ & 170.1 \\
\hline PU-N ${ }_{180 \mathrm{~kg} / \mathrm{ha}}^{180 \mathrm{k} / \mathrm{ha}}+\mathrm{PM}_{3 \text { tha }}^{2 \text { t/ha }}$ & 48.70 b-e & $1371 \quad c-i$ & 12.72 b-d & 177.1 \\
\hline PU-N & 43.33 b-e & 1418 & 11.74 & 183.0 \\
\hline PU-N ${ }_{180 \mathrm{~kg} / \mathrm{ha}}^{180 \mathrm{k} / \mathrm{ha}}+\mathrm{CD}_{5 \mathrm{t} / \mathrm{ha}}^{3 \mathrm{t} / \mathrm{ha}}$ & 43.42 b-e & 1458 & 11.20 & 188.1 \\
\hline $\mathrm{CV}(\%)$ & 9.97 & 6.57 & 7.27 & 7.60 \\
\hline $\mathrm{SE}( \pm 0.05)$ & 2.706 & 52.73 & 0.4997 & 7.876 \\
\hline
\end{tabular}

Figure(s) in a column having common letter(s) do not differ significantly at 5\% level of DMRT

TABLE 6. Integrated effect of different levels of inorganic and organic sources of $\mathrm{N}$ on head size of broccoli

\begin{tabular}{|c|c|c|}
\hline Treatment & Head length $(\mathrm{cm})$ & Head diameter $(\mathrm{cm})$ \\
\hline $\mathrm{USG} \mathrm{N}_{140 \mathrm{~kg} / \mathrm{ha}}+\mathrm{OC}_{1 \mathrm{t} / \mathrm{ha}}$ & 13.67 & $13.90 \mathrm{c}$ \\
\hline USG-N $_{140 \mathrm{~kg} / \mathrm{ha}}+\mathrm{OC}_{2 \mathrm{t} / \mathrm{ha}}$ & 13.53 & $17.43 \mathrm{ab}$ \\
\hline $\mathrm{USG}^{-N_{140 \mathrm{~kg} / \mathrm{ha}}^{140 \mathrm{~kg} / \mathrm{a}}}+\mathrm{PM}_{2 \mathrm{t} / \mathrm{ha}}^{2 \mathrm{t} / \mathrm{a}}$ & 13.83 & $16.93 \mathrm{ab}$ \\
\hline $\mathrm{USG}^{-N_{140 \mathrm{~kg} / \mathrm{ha}}}+\mathrm{PM}_{3 \mathrm{t} / \mathrm{ha}}$ & 13.63 & $17.60 \mathrm{ab}$ \\
\hline USG-N ${ }_{140 \mathrm{~kg} / \mathrm{ha}}^{140 \mathrm{~kg} / \mathrm{ha}}+\mathrm{CD}_{3 \mathrm{t} / \mathrm{ha}}$ & 14.30 & $16.83 \mathrm{ab}$ \\
\hline USG-N ${ }_{140 \mathrm{~kg} / \mathrm{ha}}^{140 \mathrm{~kg}}+\mathrm{CD}_{5 \mathrm{t} / \mathrm{ha}}$ & 13.77 & $17.67 \mathrm{ab}$ \\
\hline 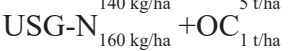 & 14.07 & $17.47 \mathrm{ab}$ \\
\hline USG-N $_{160 \mathrm{~kg} / \mathrm{ha}}+\mathrm{OC}_{2 \mathrm{t} / \mathrm{ha}}$ & 13.57 & $18.17 \mathrm{a}$ \\
\hline $\mathrm{USG}^{-N_{160 \mathrm{~kg} / \mathrm{ha}}^{160 \mathrm{~kg} / \mathrm{a}}}+\mathrm{PM}_{2 \mathrm{t} / \mathrm{ha}}^{2 \mathrm{t} / \mathrm{a}}$ & 14.30 & $17.23 \mathrm{ab}$ \\
\hline $\mathrm{USG} \mathrm{N}_{160 \mathrm{~kg} / \mathrm{ha}}+\mathrm{PM}_{3 \mathrm{t} / \mathrm{ha}}$ & 14.10 & $18.17 \mathrm{a}$ \\
\hline USG-N $_{160 \mathrm{~kg} / \mathrm{ha}}+\mathrm{CD}_{3 \mathrm{t} \text { /ha }}$ & 14.23 & $17.03 \mathrm{ab}$ \\
\hline USG-N $_{160 \mathrm{~kg} / \mathrm{ha}}+\mathrm{CD}_{5 \text { tha }}$ & 13.87 & $18.00 \mathrm{ab}$ \\
\hline 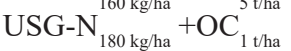 & 13.77 & $17.33 \mathrm{ab}$ \\
\hline $\mathrm{USG} \mathrm{N}_{180 \mathrm{~kg} / \mathrm{ha}}+\mathrm{OC}_{2 \mathrm{t} / \mathrm{ha}}$ & 13.33 & $18.10 \mathrm{a}$ \\
\hline USG-N $_{180 \mathrm{~kg} / \mathrm{ha}}+\mathrm{PM}_{2 \mathrm{tha}}$ & 14.50 & $17.43 \mathrm{ab}$ \\
\hline $\mathrm{USG}^{-N_{180 \mathrm{~kg} / \mathrm{ha}}}+\mathrm{PM}_{3 \mathrm{t} / \mathrm{ha}}$ & 13.70 & $17.53 \mathrm{ab}$ \\
\hline $\mathrm{USG} \mathrm{N}_{180 \mathrm{~kg} / \mathrm{ha}}+\mathrm{CD}_{3 \mathrm{t} \text { tha }}$ & 14.17 & $17.40 \mathrm{ab}$ \\
\hline $\mathrm{USG} \mathrm{N}_{180 \mathrm{~kg} / \mathrm{ha}}+\mathrm{CD}_{5 \mathrm{t} / \mathrm{ha}}$ & 13.30 & $17.80 \mathrm{ab}$ \\
\hline 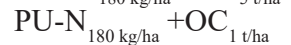 & 14.43 & $16.53 \mathrm{~b}$ \\
\hline 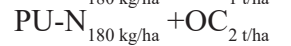 & 12.60 & $17.43 \mathrm{ab}$ \\
\hline 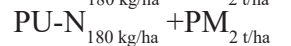 & 14.37 & $16.77 \mathrm{ab}$ \\
\hline $\mathrm{PU}-\mathrm{N}_{180 \mathrm{~kg} / \mathrm{ha}}+\mathrm{PM}_{3 \mathrm{t} / \mathrm{ha}}$ & 13.83 & $17.47 \mathrm{ab}$ \\
\hline PU-N ${ }_{180 \mathrm{~kg} / \mathrm{ha}}+\mathrm{CD}_{3 \mathrm{t} / \mathrm{ha}}$ & 14.10 & $16.93 \mathrm{ab}$ \\
\hline 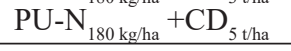 & 13.33 & $16.83 \mathrm{ab}$ \\
\hline CV $(\%)$ & 5.09 & 4.40 \\
\hline $\mathrm{SE}( \pm 0.05)$ & 0.4074 & 0.4386 \\
\hline
\end{tabular}

Figure(s) in a column having common letter(s) do not differ significantly at 5\% level of DMRT 
The head yield was also significantly influenced by the organic manure and chemical fertilizers and has followed the same trend as noted in head weight (Table 6). The highest head yield (14.75 ton $\mathrm{ha}^{-1}$ ) was observed in USG-N $\mathrm{N}_{160 \mathrm{~kg} / \mathrm{ha}}+\mathrm{OC}_{2 \text { tha }}$, which was statistically similar with USG-N ${ }_{160 \mathrm{~kg} / \mathrm{ha}}+\mathrm{PM}_{3 \mathrm{t} / \mathrm{ha}}$, USG-N $\mathrm{N}_{180 \mathrm{~kg} / \mathrm{ha}}+\mathrm{OC}_{2 \mathrm{t} / \mathrm{ha}}$ and PU-N ${ }_{180 \mathrm{~kg} /}$ $+\mathrm{PM}_{3 \text { th }}$ but significantly higher than the other treatments. The lowest head yield (11.8 t/ha) was recorded in USG$\mathrm{N}_{140 \mathrm{~kg} / \mathrm{ha}}+\mathrm{CD}_{3 \text { tha }}$, which was statistically identical to USG$\mathrm{N}_{140 \mathrm{~kg} / \mathrm{ha}}+\mathrm{PM}_{2 \mathrm{t} / \mathrm{ha}}$. It was observed that the treatment combinations of USG-N $\mathrm{N}_{160 \mathrm{~kg} / \mathrm{ha}}+\mathrm{OC}_{2 \text { tha }}, \mathrm{USG}_{16 \mathrm{~kg} / \mathrm{ha}}+\mathrm{PM}_{3 \mathrm{t} /}$ ha, USG-N $\mathrm{N}_{180 \mathrm{~kg} / \mathrm{ha}}+\mathrm{OC}_{2 \mathrm{t} / \mathrm{ha}}$ and PU-N $\mathrm{N}_{180 \mathrm{~kg} / \mathrm{ha}}+\mathrm{PM}_{3 \mathrm{t} / \mathrm{ha}}$ showed higher yield and this might be due to higher nutrient availability, continuous and uniform supply of $\mathrm{N}$ that caused optimum growth and induced maximum marketable head yield. Mustard oilcake supplied more available $\mathrm{N}$ to crop where maximum vegetative growth was occurred. The lowest head yield of broccoli might be owing to insufficient supply of nutrients leading to limited carbon assimilation, resulting in reduction of plant productivity (Lawlor 2002; Shangguan et al. 2000). Abou El-Magd (2006) reported the highest total yield of broccoli by application of $100 \%$ cattle manure plus poultry manure. Similar results were also observed by Yoldas et al. (2008) in broccoli production.

\section{HARVEST INDEX}

Harvest index was not significantly influenced but the maximum harvest index (27.71) was observed in USG-
$\mathrm{N}_{160 \mathrm{~kg} / \mathrm{ha}}+\mathrm{PM}_{3 \text { th } \mathrm{ha}}$ followed by PU-N $\mathrm{N}_{180 \mathrm{~kg} / \mathrm{ha}}+\mathrm{OC}_{1 \text { th } \mathrm{ha}}(27.28)$ and $\mathrm{USG} \mathrm{N}_{160 \mathrm{~kg} / \mathrm{ha}}+\mathrm{OC}_{2 \mathrm{tha}}(27.21)$. However, harvest index (27.21) from USG-N $\mathrm{N}_{160 \mathrm{~kg} / \mathrm{ha}}+\mathrm{OC}_{2 \mathrm{t} / \mathrm{ha}}$ that produced the highest head weight (398.3 $\mathrm{g} \mathrm{plant}^{-1}$ ) as well as head yield (14.75 ton $\mathrm{ha}^{-1}$ ) (Table 7). This might be due to higher biomass yield as influenced by the higher $\mathrm{N}$ uptake in relation to economic yield. The results from this study indicated that higher dose of nitrogenous fertilizer application did not always give the higher harvest index and yield (Table 6).

\section{LATERAL HEAD WEIGHT PER PLANT}

Lateral head weight $\left(\mathrm{g} \mathrm{plant}^{-1}\right)$ was significantly influenced by the different treatment combinations (Table 7). USG $_{180 \mathrm{~kg}}$ ha $+\mathrm{PM}_{3 \text { th }}$ showed the maximum lateral head weight (178.5 $\mathrm{g}$ plant $\left.{ }^{-1}\right)$ which was closely followed by $\mathrm{USG}_{160 \mathrm{~kg} / \mathrm{ha}}+\mathrm{PM}_{3 \mathrm{t} /}$ ha. The lowest lateral head weight $\left(91.8 \mathrm{~g}\right.$ plant $\left.^{-1}\right)$ was recorded in $\mathrm{USG}_{140 \mathrm{tha}}+\mathrm{CD}_{3 \text { tha }}$ followed by $\mathrm{USG}_{140 \text { tha }}+\mathrm{PM}_{2 \mathrm{t}}$ ha. The lateral head weight in $\mathrm{USG}_{180 \mathrm{~kg} / \mathrm{ha}}+\mathrm{PM}_{3 \mathrm{t} / \mathrm{ha}}$ and $\mathrm{USG}_{160 \mathrm{~kg} / \mathrm{ha}}+\mathrm{PM}_{3 \mathrm{tha}}$ and this might be due to effect of organic matter and long term N supplying capacity of USG which may increase higher growth. This finding was supported by Yoldas et al. (2008) where $\mathrm{N}$ rates significantly increased yield, average weight of main and lateral head.

\section{LATERAL HEAD YIELD}

Lateral head yield was significantly variable among the different treatment combinations (Table 7). The highest

TABLE 7. Integrated effect of different levels of inorganic and organic sources of $\mathrm{N}$ on yield and yield attributes of broccoli

\begin{tabular}{|c|c|c|c|c|}
\hline Treatment & Head weight (g plant $\left.{ }^{-1}\right)$ & Head dry wt. (g plant ${ }^{-1}$ ) & Head yield $\left(\mathrm{t} \mathrm{ha}^{-1}\right)$ & Harvest index $(\%)$ \\
\hline $\mathrm{USG} \mathrm{N}_{140 \mathrm{~kg} / \mathrm{ha}}+\mathrm{OC}_{1 \mathrm{t} / \mathrm{ha}}$ & $328.3 \mathrm{hi}$ & $54.18 \mathrm{gh}$ & $12.16 \mathrm{hi}$ & 21.76 \\
\hline USG-N $N_{140 \mathrm{~kg} / \mathrm{ha}}^{140 \mathrm{k} / \mathrm{ha}}+\mathrm{OC}_{2 \mathrm{t} / \mathrm{ha}}$ & 356.1 b-f & 58.76 b-e & $13.19 \mathrm{~b}-\mathrm{f}$ & 23.20 \\
\hline $\mathrm{USG}^{-N_{140 \mathrm{~kg} / \mathrm{ha}}^{140 \mathrm{~kg} / \mathrm{ha}}}+\mathrm{PM}_{2 \mathrm{t} / \mathrm{ha}}^{2 \mathrm{t} / \mathrm{a} \mathrm{a}}$ & $321.7 \mathrm{i}$ & $53.08 \mathrm{~h}$ & $11.91 \mathrm{i}$ & 26.74 \\
\hline $\mathrm{USG} \mathrm{N}_{140 \mathrm{~kg} / \mathrm{ha}}^{140 \mathrm{~kg} / \mathrm{PM}}+\mathrm{PM}_{3 \mathrm{tha}}^{2 \text { ha }}$ & 342.5 d-h & 56.51 d-g & $12.69 \mathrm{~d}-\mathrm{h}$ & 26.17 \\
\hline $\mathrm{USG} \mathrm{N}_{140 \mathrm{~kg} / \mathrm{ha}}^{140 \mathrm{~kg} / \mathrm{CD}}+\mathrm{CD}_{3 \text { tha }}^{3 \text { tha }}$ & $320.5 \mathrm{i}$ & $52.88 \mathrm{~h}$ & $11.87 \mathrm{i}$ & 24.45 \\
\hline $\mathrm{USG} \mathrm{N}_{140 \mathrm{~kg} / \mathrm{ha}}+\mathrm{CD}_{5 \mathrm{t} / \mathrm{ha}}$ & 349.5 b-f & 57.67 b-e & $12.95 \mathrm{~b}-\mathrm{f}$ & 25.62 \\
\hline $\mathrm{USG} \mathrm{N}_{160 \mathrm{~kg} / \mathrm{ha}}^{140 \mathrm{~kg} \text { ha }}+\mathrm{OC}_{1 \text { tha }}^{\text {Jina }}$ & 362.3 b-e & 59.79 b-d & 13.42 b-e & 26.90 \\
\hline $\mathrm{USG} \mathrm{N}_{160 \mathrm{~kg} / \mathrm{ha}}^{100 \mathrm{~kg} / \mathrm{OC}}+\mathrm{OC}_{2 \text { tha }}$ & 398.3 a & 65.73 a & $14.75 \mathrm{a}$ & 27.21 \\
\hline $\mathrm{USG} \mathrm{N}_{160 \mathrm{~kg} / \mathrm{ha}}^{100 \mathrm{~kg}}+\mathrm{PM}_{2 \text { tha }}^{20 \mathrm{ha}}$ & $345.8 \mathrm{c}-\mathrm{h}$ & 56.43 d-g & $12.81 \mathrm{c}-\mathrm{h}$ & 25.40 \\
\hline $\mathrm{USG} \mathrm{N}_{160 \mathrm{~kg} / \mathrm{ha}}+\mathrm{PM}_{3 \mathrm{t} / \mathrm{ha}}^{2 \mathrm{~kg} / \mathrm{ha}}$ & $373.6 \mathrm{~b}$ & $61.65 \mathrm{~b}$ & $13.84 \mathrm{a}$ & 27.71 \\
\hline $\mathrm{USG} \mathrm{N}_{160 \mathrm{~kg} / \mathrm{ha}}+\mathrm{CD}_{3 \mathrm{t} \text { tha }}$ & 351.7 b-f & 58.03 b-e & $13.02 \mathrm{~b}-\mathrm{f}$ & 27.14 \\
\hline $\mathrm{USG} \mathrm{N}_{160 \mathrm{~kg} / \mathrm{ha}}^{100 \mathrm{~kg} / \mathrm{CD}}+\mathrm{CD}_{5 \text { tha }}^{\text {3tha }}$ & 358.8 b-e & 59.21 b-d & 13.29 b-e & 27.12 \\
\hline USG-N $N_{180 \mathrm{~kg} / \mathrm{ha}}^{100 \mathrm{~kg} / \mathrm{Oa}}+\mathrm{OC}_{1 \mathrm{t} / \mathrm{ha}} \mathrm{stha}$ & 361.7 b-e & 59.68 b-d & 13.40 b-e & 26.13 \\
\hline $\mathrm{USG} \mathrm{N}_{180 \mathrm{~kg} / \mathrm{ha}}+\mathrm{OC}_{2 \text { tha }}$ & $391.0 \mathrm{a}$ & 64.52 a & 14.48 a & 24.27 \\
\hline $\mathrm{USG} \mathrm{N}_{180 \mathrm{~kg} / \mathrm{ha}}+\mathrm{PM}_{2 \mathrm{t} / \mathrm{ha}}$ & 342.0 e-h & $57.06 \quad \mathrm{c}-\mathrm{g}$ & 12.67 e-h & 23.16 \\
\hline $\mathrm{USG} \mathrm{N}_{180 \mathrm{~kg} / \mathrm{ha}}+\mathrm{PM}_{3 \mathrm{t} / \mathrm{ka}}^{2 \text { ha }}$ & $366.7 \mathrm{bc}$ & $60.50 \mathrm{bc}$ & $13.58 \mathrm{bc}$ & 24.41 \\
\hline $\mathrm{USG} \mathrm{N}_{180 \mathrm{~kg} / \mathrm{ha}}+\mathrm{CD}_{3 \mathrm{t} \text { tha }}$ & 336.7 f-i & 55.55 e-h & $12.47 \mathrm{f}-\mathrm{i}$ & 24.43 \\
\hline $\mathrm{USG} \mathrm{N}_{180 \mathrm{~kg} / \mathrm{ha}}+\mathrm{CD}_{5 \mathrm{t} / \mathrm{ha}}$ & 359.3 b-e & 59.29 b-d & 13.31 b-e & 25.13 \\
\hline PU-N & 348.7 b-g & 57.53 b-f & $12.91 \mathrm{~b}-\mathrm{g}$ & 27.28 \\
\hline PU-N ${ }_{180 \mathrm{~kg} / \mathrm{ha}}^{180 \mathrm{k} / \mathrm{ha}}+\mathrm{OC}_{2 \text { tha }}^{1 \text { tha }}$ & $369.2 \mathrm{~b}$ & 60.91 b & $13.67 \mathrm{~b}$ & 26.68 \\
\hline PU-N $180 \mathrm{~kg} / \mathrm{ha}=\mathrm{PM}_{2 \mathrm{t} / \mathrm{ha}}$ & 353.3 b-f & 54.18 f-h & 13.09 b-f & 26.79 \\
\hline 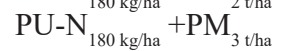 & $370.5 \mathrm{~b}$ & $61.14 \mathrm{~b}$ & $13.72 \mathrm{a}$ & 27.02 \\
\hline PU-N ${ }_{180 \mathrm{~kg} / \mathrm{ha}}+\mathrm{CD}_{3 \mathrm{t} \text { /ha }}$ & $328.3 \mathrm{~g}-\mathrm{i}$ & $58.30 \quad$ b-e & $12.16 \mathrm{~g}-\mathrm{i}$ & 23.15 \\
\hline $\mathrm{PU}-\mathrm{N}_{180 \mathrm{~kg} / \mathrm{ha}}+\mathrm{CD}_{5 \mathrm{t} / \mathrm{ha}}$ & 357.8 b-f & 59.03 b-d & $13.25 \mathrm{~b}-\mathrm{f}$ & 24.54 \\
\hline $\mathrm{CV}(\%)$ & 3.09 & 3.06 & 3.09 & - \\
\hline $\mathrm{SE}( \pm 0.05)$ & 6.306 & 1.029 & 0.2338 & - \\
\hline
\end{tabular}

Figure(s) in a column having common letter(s) do not differ significantly at 5\% level of DMRT 
TABLE 8. Integrated effect of different forms and levels of inorganic and organic sources of $\mathrm{N}$ on the yield of lateral head of broccoli

\begin{tabular}{|c|c|c|}
\hline Treatment & Lateral head weight (g plant $\left.{ }^{-1}\right)$ & Lateral head yield $\left(\mathrm{t} \mathrm{ha}^{-1}\right)$ \\
\hline USG-N ${ }_{140 \mathrm{~kg} / \mathrm{ha}}+\mathrm{OC}_{1 \mathrm{t} / \mathrm{ha}}$ & $106.5 \mathrm{~g}-\mathrm{i}$ & 3.944 g-i \\
\hline USG-N ${ }_{140 \mathrm{~kg} / \mathrm{ha}}^{140}+\mathrm{OC}_{2 \text { tha }}^{1 \text { tha }}$ & 117.8 e-h & 4.361 e-h \\
\hline USG-N ${ }_{140 \mathrm{~kg} / \mathrm{ha}}^{140 \mathrm{kga}}+\mathrm{PM}_{2 \text { tha }}^{2 \text { t/ha }}$ & 100.7 h-i & $3.730 \mathrm{~h}-\mathrm{i}$ \\
\hline 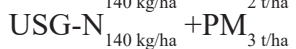 & $106.3 \mathrm{~g}-\mathrm{i}$ & 3.939 g-i \\
\hline USG-N ${ }_{140 \mathrm{~kg} / \mathrm{ha}}^{140 \mathrm{~g} / \mathrm{ha}}+\mathrm{CD}_{3 \mathrm{t} \text { /ha }}^{3 \text { tha }}$ & $91.8 \mathrm{i}$ & $3.401 \mathrm{i}$ \\
\hline USG-N ${ }_{140 \mathrm{~kg} / \mathrm{ha}}^{140 \mathrm{~kg}}+\mathrm{CD}_{5 \mathrm{t} / \mathrm{ha}}^{3 \text { tha }}$ & $104.2 \mathrm{~h}-\mathrm{i}$ & 3.858 h-i \\
\hline $\mathrm{USG} \mathrm{N}_{160 \mathrm{~kg} / \mathrm{ha}}^{140 \mathrm{~kg} / \mathrm{ha}}+\mathrm{OC}_{1 \mathrm{t} / \mathrm{ha}}^{5 \text { tha }}$ & $113.3 \mathrm{f}-\mathrm{i}$ & $4.198 \mathrm{f}-\mathrm{i}$ \\
\hline USG-N ${ }_{160 \mathrm{~kg} / \mathrm{ha}}^{160 \mathrm{~kg} h}+\mathrm{OC}_{2 \text { tha }}^{1 \text { tha }}$ & $142.4 \quad \mathrm{c}-\mathrm{e}$ & 5.274 c-e \\
\hline USG-N $N_{160 \mathrm{~kg} / \mathrm{ha}}^{160 \mathrm{k} / \mathrm{ha}}+\mathrm{PM}_{2 \text { tha }}^{2 \text { tha }}$ & $116.3 \mathrm{f}-\mathrm{i}$ & $4.307 \mathrm{f}-\mathrm{i}$ \\
\hline USG-N & $178 \mathrm{a}$ & $6.61 \mathrm{a}$ \\
\hline USG-N $N_{160 \mathrm{~kg} / \mathrm{ha}}^{160 \mathrm{~kg} / \mathrm{ha}}+\mathrm{CD}_{3 \text { t/ha }}^{3 \text { tha }}$ & $123.8 \mathrm{~d}-\mathrm{h}$ & 4.584 d-h \\
\hline USG-N ${ }_{160 \mathrm{~kg} / \mathrm{ha}}^{160 \mathrm{~kg} h}+\mathrm{CD}_{5 \text { tha }}^{3 \text { tha }}$ & $131.5 \mathrm{c}-\mathrm{g}$ & $4.872 \mathrm{c}-\mathrm{g}$ \\
\hline USG-N $N_{180 \mathrm{~kg} / \mathrm{ha}}^{160 \mathrm{~kg} h}+\mathrm{OC}_{1 \text { tha }}^{\text {tha }}$ & $152.3 \mathrm{bc}$ & $5.640 \mathrm{bc}$ \\
\hline USG-N & $146.5 \mathrm{~b}-\mathrm{d}$ & 5.427 b-d \\
\hline USG-N ${ }_{180 \mathrm{~kg} / \mathrm{ha}}^{180 \mathrm{~kg}}+\mathrm{PM}_{2 \text { tha }}^{2 \text { tha }}$ & $145.6 \mathrm{~b}-\mathrm{d}$ & $5.393 \mathrm{~b}-\mathrm{d}$ \\
\hline USG-N ${ }_{180 \mathrm{~kg} / \mathrm{ha}}^{180 \mathrm{~g} / \mathrm{Pa}} \mathrm{PM}_{3 \text { tha }}^{2 \text { tha }}$ & $178.5 \mathrm{a}$ & $6.612 \mathrm{a}$ \\
\hline USG-N ${ }_{180 \mathrm{~kg} / \mathrm{ha}}^{180 \mathrm{~g} / \mathrm{C}}+\mathrm{CD}_{3 \mathrm{t} \text { /ha }}^{3 \text { tha }}$ & $130.6 \mathrm{c}-\mathrm{g}$ & $4.837 \mathrm{c}-\mathrm{g}$ \\
\hline USG-N & $166.5 \mathrm{ab}$ & $6.167 \mathrm{ab}$ \\
\hline PU-N ${ }_{180 \mathrm{~kg} / \mathrm{ha}}^{180 \mathrm{~kg}}+\mathrm{OC}_{1 \text { tha }}^{\text {tha }}$ & $103.3 \mathrm{~h}-\mathrm{i}$ & $3.826 \mathrm{~h}-\mathrm{i}$ \\
\hline $\mathrm{PU}-\mathrm{N}_{18 \mathrm{~kg} \text { na }}+\mathrm{OC}_{2}$ & $124.6 \mathrm{~d}-\mathrm{h}$ & $4.616 \mathrm{~d}-\mathrm{h}$ \\
\hline PU-N ${ }_{180 \mathrm{~kg} / \mathrm{ha}}^{180 \mathrm{kga}}+\mathrm{PM}_{2 \text { tha }}^{2 \text { t/ha }}$ & $101.2 \mathrm{~h}-\mathrm{i}$ & 3.749 h-i \\
\hline $\mathrm{PU}-\mathrm{N}^{180 \mathrm{~kg} \text { na }}+\mathrm{PM}_{3}^{2 \mathrm{tha}}$ & $166 \mathrm{ab}$ & $4.691 \mathrm{~d}-\mathrm{h}$ \\
\hline PU-N ${ }_{180 \mathrm{~kg} / \mathrm{ha}}^{180 \mathrm{~kg} h}+\mathrm{CD}_{3 \text { tha }}^{3 \text { t/ha }}$ & $106.9 \mathrm{f}-\mathrm{i}$ & $3.961 \mathrm{f}-\mathrm{i}$ \\
\hline PU-N ${ }_{180 \mathrm{~kg} / \mathrm{ha}}^{180 \mathrm{~kg} / \mathrm{ha}}+\mathrm{CD}_{5 \mathrm{t} / \mathrm{ha}}^{3}$ & $163 \mathrm{ab}$ & $4.646 \mathrm{~d}-\mathrm{h}$ \\
\hline CV (\%) & 10.56 & 10.56 \\
\hline $\mathrm{SE}( \pm 0.05)$ & 7.611 & 0.2817 \\
\hline
\end{tabular}

Figure(s) in a column having common letter(s) do not differ significantly at $5 \%$ level of DMRT

lateral head yield $\left(6.61 \mathrm{t} \mathrm{ha}^{-1}\right)$ was found in USG-N ${ }_{160 \mathrm{~kg} /}$ ha $+\mathrm{PM}_{3 \mathrm{t} / \mathrm{ha}}$ and $\mathrm{USG}_{180 \mathrm{~kg} / \mathrm{ha}}+\mathrm{PM}_{3 \mathrm{t} / \mathrm{ha}}$ which were statistically identical to $\mathrm{USG}_{180 \mathrm{~kg} / \mathrm{ha}}+\mathrm{CD}_{5 \text { t/ha }}$ and significantly higher than the other treatments. The lowest lateral head yield $\left(3.40 \mathrm{t} \mathrm{ha}^{-1}\right)$ was noted in $\mathrm{USG}_{140 \mathrm{~kg} / \mathrm{ha}}+\mathrm{CD}_{3 \mathrm{t} / \mathrm{ha}}$. This higher lateral head yield might be due to the slow release of nutrients from organic matter and long-duration $\mathrm{N}$ supplying capacity of USG. The continuous supply of $\mathrm{N}$ might have resulted in better translocation of carbohydrates to storage organs, which influenced the weight of lateral heads. This result is in agreement with the findings of Yoldas et al. (2008) who reported that $\mathrm{N}$ rates significantly increased yield, average weight of main and lateral head yield. Similar result was also observed by Bhardwaj et al. (2007) and Kumar et al. (2012) in sprouting broccoli.

\section{ECONOMIC EVALUATION}

The production cost of broccoli varied due to the effect of organic manures along with differential amount of $\mathrm{N}$ fertilizer as USG and PU (Table 8). The highest total variable cost $\left(\$ 1867.6 \mathrm{ha}^{-1}\right)$ was found in PU-N ${ }_{180 \mathrm{~kg} /}$ ha $+\mathrm{OC}_{2 \mathrm{t} / \mathrm{ha}}$ followed by USG-N $\mathrm{1}_{18 \mathrm{~kg} / \mathrm{ha}}+\mathrm{OC}_{2 \mathrm{tha}}\left(\$ 1837.1 \mathrm{ha}^{-1}\right)$, USG-N $_{160 \mathrm{~kg} / \mathrm{ha}}+\mathrm{OC}_{2 \mathrm{t} \text { ha }}\left(\$ 1826.9 \mathrm{ha}^{-1}\right)$ and USG-N ${ }_{140 \mathrm{~kg} / \mathrm{ha}}+\mathrm{OC}_{2 \mathrm{t}}$ ha $\left(\$ 1808.50 \mathrm{ha}^{-1}\right)$. The reason behind higher costs in these treatments was due to higher cost of mustard oil cake.
The lowest variable costs ( $\$ 1197.7$ ha-1) were recorded in USG-N140kg/ha+PM ${ }_{2 \text { tha }}$, where lower recommended dose of chemical fertilizers and $2 \mathrm{t}$ /ha poultry manure was used. The maximum gross return $\left(\$ 5274.6 \mathrm{ha}^{-1}\right)$ and gross margin ( $\$ 3711.7 \mathrm{ha}^{-1}$ ) were found in USG-N ${ }_{160 \mathrm{~kg} /}$ ha $+\mathrm{OC}_{2 \mathrm{t} / \mathrm{ha}}$ and USG-N $\mathrm{N}_{160 \mathrm{~kg} / \mathrm{ha}}+\mathrm{PM}_{3 \mathrm{t} / \mathrm{ha}}$, respectively. The highest benefit-cost ratio (4.0) was observed in USG-N $\mathrm{N}_{160 \mathrm{~kg} /}$ ha $+\mathrm{PM}_{3 \mathrm{t} / \mathrm{ha}}$ followed by USG-N ${ }_{180 \mathrm{~kg} / \mathrm{ha}}+\mathrm{PM}_{3 \mathrm{t} \text { ha }}$ (3.90). The lowest benefit cost ratio (BCR) (2.61) was noted in PU$\mathrm{N}_{140 \mathrm{~kg} / \mathrm{ha}}+\mathrm{OC}_{2 \mathrm{tha}}$. Moreover, PU-N $\mathrm{N}_{180 \mathrm{~kg} / \mathrm{ha}}+\mathrm{PM}_{3 \mathrm{th} \mathrm{ha}}$ showed the higher BCR 3.84 with gross margin (GM) \$ 3639.57 ha $^{-1}$ followed by PU-N ${ }_{180 \mathrm{~kg} / \mathrm{ha}}+\mathrm{CD}_{5 \mathrm{t} / \mathrm{ha}}$ (BCR 3.65 with gross margin \$3494.49 $\mathrm{ha}^{-1}$ ) (Table 9). The highest marginal rate of return (MRR) was found in USG-N $\mathrm{N}_{160 \text { tha }}+\mathrm{PM}_{3 \mathrm{t} / \mathrm{ha}}$ $(132.42 \%)$ followed by USG-N ${ }_{160 \mathrm{~kg} / \mathrm{ha}}+\mathrm{PM}_{2 \mathrm{t} / \mathrm{ha}}(32.34 \%)$ and USG-N $\mathrm{N}_{160 \mathrm{~kg} / \mathrm{ha}}+\mathrm{CD}_{3 \mathrm{t} / \mathrm{ha}}(9.01 \%)$. Among PU, PU-N ${ }_{180 \mathrm{~kg} /}$ ha $+\mathrm{PM}_{3 \mathrm{t} \text { ha }}$ showed cost un-dominated performance (MRR $18.05 \%$ ) with BCR 3.84 which was economically profitable (Table 9). Although the higher yield and gross returns were found in USG-N $\mathrm{N}_{180 \mathrm{~kg} / \mathrm{ha}}+\mathrm{OC}_{2 \text { tha }}$ but economically it was not viable. However, $160 \mathrm{~kg} \mathrm{~N}$ as USG with 3 ton poultry manure (USG-N $\mathrm{N}_{160 \mathrm{t} / \mathrm{ha}} \times \mathrm{PM}_{3 \mathrm{t} / \mathrm{ha}}$ ) produced considerably higher yield with highest MRR (132.42\%). It was recognized that any technology could be economically viable if it's BCR, MBCR and MRR are more than 1,2 and $50 \%$, respectively. This economic benefit might be due to balanced nutrient supply which optimizes 
TABLE 9. Partial budget analysis (with dominance analysis) of broccoli production as influenced by different levels of inorganic (USG) and organic sources of $\mathrm{N}$

\begin{tabular}{|c|c|c|c|c|c|c|c|c|}
\hline Treatment & $\begin{array}{l}\text { Yield } \\
\left(\mathrm{t} \mathrm{ha}^{-1}\right)\end{array}$ & $\begin{array}{l}\text { G. Return } \\
\left(\$ \mathrm{ha}^{-1}\right)\end{array}$ & $\begin{array}{l}\text { TVC }^{*} \\
\left(\$ \mathrm{ha}^{-1}\right)\end{array}$ & $\begin{array}{c}\mathrm{GM} \\
\left(\$ \mathrm{ha}^{-1}\right)\end{array}$ & $\begin{array}{c}\operatorname{MVC}(\$ \\
\left.\text { ha }^{-1}\right)\end{array}$ & $\begin{array}{c}\operatorname{MGM}(\$ \\
\left.\mathrm{ha}^{-1}\right)\end{array}$ & $\mathrm{BCR}$ & $\begin{array}{l}\text { MRR } \\
(\%)\end{array}$ \\
\hline $\mathrm{USG} \mathrm{N}_{140 \mathrm{~kg} / \mathrm{ha}}+\mathrm{PM}_{2 \text { thh }}$ & 11.910 & 4259.02 & 1197.71 & 3061.31 & - & - & 3.56 & - \\
\hline USG-N $N_{140 \mathrm{~kg} / \mathrm{ha}}+\mathrm{CD}_{3 \text { tha }}$ & 11.870 & 4244.71 & 1206.75 & 3037.97 & 9.04 & $\mathrm{D}$ & 3.52 & - \\
\hline $\mathrm{USG} \mathrm{N}_{160 \mathrm{~kg} / \mathrm{ha}}+\mathrm{PM}_{2 \text { thh }}$ & 12.810 & 4580.86 & 1216.13 & 3364.73 & 9.38 & 303.42 & 3.77 & 32.34 \\
\hline $\mathrm{USG} \mathrm{N}_{140 \mathrm{~kg} / \mathrm{ha}}+\mathrm{PM}_{3 \text { tha }}$ & 12.690 & 4537.94 & 1217.83 & 3320.11 & 1.70 & $\mathrm{D}$ & 3.73 & - \\
\hline USG-N ${ }_{160 \mathrm{~kg} / \mathrm{ha}}+\mathrm{CD}_{3 \text { tha }}$ & 13.020 & 4655.95 & 1225.16 & 3430.79 & 7.33 & 66.06 & 3.80 & 9.01 \\
\hline USG-N ${ }_{180 \mathrm{~kg} / \mathrm{ha}}+\mathrm{PM}_{2 \text { tha }}$ & 12.670 & 4530.79 & 1226.28 & 3304.51 & 1.12 & $\mathrm{D}$ & 3.69 & - \\
\hline USG-N ${ }_{180 \mathrm{~kg} / \mathrm{ha}}+\mathrm{CD}_{3 \text { tha }}$ & 12.470 & 4459.27 & 1235.32 & 3223.95 & 9.04 & $\mathrm{D}$ & 3.61 & - \\
\hline $\mathrm{USG} \mathrm{N}_{160 \mathrm{~kg} / \mathrm{ha}}+\mathrm{PM}_{3 \text { tha }}$ & 13.840 & 4949.18 & 1237.44 & 3711.74 & 2.12 & 280.95 & 4.00 & 132.42 \\
\hline USG-N $_{140 \mathrm{~kg} / \mathrm{ha}}+\mathrm{CD}_{5 \text { tha }}$ & 12.950 & 4630.92 & 1239.60 & 3391.32 & 2.16 & $\mathrm{D}$ & 3.74 & - \\
\hline $\mathrm{USG} \mathrm{N}_{180 \mathrm{~kg} / \mathrm{ha}}+\mathrm{PM}_{3 \text { tha }}$ & 13.580 & 4856.21 & 1246.40 & 3609.81 & 6.81 & $\mathrm{D}$ & 3.90 & - \\
\hline USG-N ${ }_{160 \mathrm{kgha}}+\mathrm{CD}_{5 \text { tha }}$ & 13.290 & 4752.50 & 1258.01 & 3494.49 & 1.57 & $\mathrm{D}$ & 3.78 & - \\
\hline USG-N $_{180 \mathrm{~kg} / \mathrm{ha}}+\mathrm{CD}_{5 \text { tha }}$ & 13.310 & 4759.66 & 1268.17 & 3491.49 & 2.83 & $\mathrm{D}$ & 3.75 & - \\
\hline USG-N $_{140 \mathrm{~kg} / \mathrm{ha}}+\mathrm{OC}_{1 \text { tha }}$ & 12.160 & 4348.42 & 1482.98 & 2865.44 & 184.66 & $\mathrm{D}$ & 2.93 & - \\
\hline $\mathrm{USG} \mathrm{N}_{180 \mathrm{kgha}}+\mathrm{OC}_{1 \text { tha }}$ & 13.400 & 4791.84 & 1511.55 & 3280.29 & 28.57 & $\mathrm{D}$ & 3.17 & - \\
\hline USG-N $_{160 \mathrm{~kg} / \mathrm{ha}}+\mathrm{OC}_{1 \text { tha }}$ & 13.420 & 4798.99 & 1513.32 & 3285.68 & 1.76 & $\mathrm{D}$ & 3.17 & - \\
\hline $\mathrm{USG} \mathrm{N}_{140 \mathrm{~kg} / \mathrm{ha}}+\mathrm{OC}_{2 \text { tha }}$ & 13.190 & 4716.74 & 1808.50 & 2908.25 & 266.76 & $\mathrm{D}$ & 2.61 & - \\
\hline $\mathrm{USG} \mathrm{N}_{160 \mathrm{~kg} / \mathrm{ha}}+\mathrm{OC}_{2 \text { tha }}$ & 14.750 & 5274.60 & 1826.92 & 3447.68 & 18.42 & $\mathrm{D}$ & 2.89 & - \\
\hline $\mathrm{USG} \mathrm{N}_{180 \mathrm{~kg} / \mathrm{ha}}+\mathrm{OC}_{2 \text { tha }}$ & 14.480 & 5178.05 & 1837.07 & 3340.97 & 10.16 & $\mathrm{D}$ & 2.82 & - \\
\hline
\end{tabular}

Input (material) cost: Seed $=\$ 2.98 / 10 \mathrm{~g} ; \mathrm{PU}=\$ 0.14 / \mathrm{kg} ; \mathrm{USG}=\$ 0.15 / \mathrm{kg} ;$ Cow dung $=\$ 17.88 /$ ton; Poultry litter $=\$ 23.84 /$ ton; Mustard oil cake $=\$ 0.33 / \mathrm{kg} ;$ Labor $=\$ 2.05 /$ diam. Placement cost (labor ha $\left.{ }^{-1}\right)$ : Prilled urea: 56.58 labor ha- ${ }^{-1}$ ( times) common for all doses; USG: 34.29 labor for $140 \mathrm{~kg}, 39.86$ labor for $160 \mathrm{~kg}$, 41.58 labor for $180 \mathrm{~kg}$ USG per hectare. Output cost: Broccoli $=\$ 0.36 / \mathrm{kg}$; TVC*= Total variable cost. $(1 \mathrm{BDT}=0.01192$ US $\$$ )

TABLE 10. Partial budget analysis (with dominance analysis) of broccoli production as influenced by different levels of inorganic (PU) and organic sources of $\mathrm{N}$

\begin{tabular}{|c|c|c|c|c|c|c|c|c|}
\hline Treatment & $\begin{array}{l}\text { Yield } \\
\left(\text { tha }^{-1}\right)\end{array}$ & $\begin{array}{l}\text { G. Return } \\
\left(\$ \mathrm{ha}^{-1}\right)\end{array}$ & $\begin{array}{l}\text { TVC* } \\
\left(\$ \text { ha }^{-1}\right)\end{array}$ & $\begin{array}{c}\mathrm{GM} \\
\left(\$ \mathrm{ha}^{-1}\right)\end{array}$ & $\begin{array}{c}\text { MVC } \\
\left(\$ . h a^{-1}\right)\end{array}$ & $\begin{array}{l}\text { MGM } \\
\left(\$ . h a^{-1}\right)\end{array}$ & BCR & $\begin{array}{c}\text { MRR } \\
(\%)\end{array}$ \\
\hline $\mathrm{PU}-\mathrm{N}_{180 \mathrm{~kg} / \mathrm{ha}}+\mathrm{PM}_{2 \text { tha }}$ & 13.09 & 4680.98 & 1256.44 & 3424.54 & - & - & 3.73 & - \\
\hline PU-N ${ }_{180 \mathrm{~kg} / \mathrm{ha}}+\mathrm{CD}_{3 \text { tha }}$ & 12.16 & 4348.42 & 1265.34 & 3083.07 & 8.90 & $\mathrm{D}$ & 3.44 & - \\
\hline 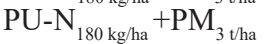 & 13.72 & 4906.27 & 1276.70 & 3629.57 & 11.36 & 205.02 & 3.84 & 18.05 \\
\hline 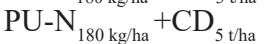 & 13.25 & 4738.20 & 1298.31 & 3439.89 & 21.61 & $\mathrm{D}$ & 3.65 & - \\
\hline PU-N ${ }_{180 \mathrm{~kg} / \mathrm{ha}}+\mathrm{OC}_{1 \text { tha }}$ & 12.91 & 4616.62 & 1541.74 & 3074.87 & 243.43 & $\mathrm{D}$ & 2.99 & - \\
\hline PU-N ${ }_{180 \mathrm{~kg} / \mathrm{ha}}+\mathrm{OC}_{2 \text { tha }}$ & 13.67 & 4888.39 & 1867.59 & 3020.80 & 325.85 & $\mathrm{D}$ & 2.62 & - \\
\hline
\end{tabular}

Input (material) cost: Seed= $\$ 2.98 / 10 \mathrm{~g} ; \mathrm{PU}=\$ 0.14 / \mathrm{kg} ; \mathrm{USG}=\$ 0.15 / \mathrm{kg} ;$ Cow dung $=\$ 17.88 /$ ton; Poultry litter $=\$ 23.84 /$ ton; Mustard oil cake $=\$ 0.33 / \mathrm{kg}$; Labor $=\$ 2.05 /$ diam. Placement cost (labor ha $\left.{ }^{-1}\right)$ : Prilled urea: 56.58 labor ha ${ }^{-1}$ (2 times) common for all doses; USG: 34.29 labor for $140 \mathrm{~kg}, 39.86$ labor for $160 \mathrm{~kg}$, 41.58 labor for $180 \mathrm{~kg}$ USG per hectare. Output cost: Broccoli $=\$ 0.36 / \mathrm{kg}$; TVC*= Total variable cost. (1 BDT=0.01192 US \$)

economic profitability. Dass et al. (2008) and Maurya et al. (2008) reported that the production potential of balanced nutrition for higher benefit-cost ratio in broccoli. Therefore, USG-N $\mathrm{N}_{160 \mathrm{~kg} / \mathrm{ha}}+\mathrm{PM}_{3 \mathrm{tha}}$ (Gross margin \$ 3711.74 $\mathrm{ha}^{-1}$ with MRR $132.42 \%$ ) and PU-N ${ }_{180 \mathrm{~kg} / \mathrm{ha}}+\mathrm{PM}_{3 \mathrm{tha}}$ (Gross margin \$3629.57 ha ${ }^{-1}$ with BCR 3.84 and MRR $18.05 \%$ ) with a gross return of $\$ 4906.27 \mathrm{ha}^{-1}$ can be the good integrated nitrogen management packages with other recommended fertilizer doses for broccoli production with economical profitability.

\section{CONCLUSION}

Urea super granule along with organic manures performed better in relation to yield and yield attributes as compared to prilled urea. The highest head yield was found in urea super granules (USG)- $\mathrm{N}_{160 \mathrm{~kg} / \mathrm{ha}}+$ Oil Cake (OC) $)_{2 \text { tha }}$ which was statistically identical to USG-N $\mathrm{N}_{160 \mathrm{~kg} / \mathrm{ha}}+$ Poultry manure $(\mathrm{PM})_{3 \text { tha }}$, USG-N $\mathrm{1}_{\text {18t ha }}+\mathrm{OC}_{2 \text { tha }}$ and PU-N 180kg ha $_{3 \text { tha }}$. The maximum lateral head yield $\left(6.61\right.$ tha $\left.^{-1}\right)$, harvest index (27.7), benefit cost ratio (BCR) (4.0) and marginal rate of return (MRR) (132.42) were observed in $\mathrm{USG} \mathrm{N}_{160 \mathrm{~kg} / \mathrm{ha}}+\mathrm{PM}_{3 \mathrm{t}}$ 
ha Among PU treatments, PU-N $\mathrm{N}_{180 \text { th }}+\mathrm{PM}_{3 \text { th }}$ showed better yield $\left(13.7\right.$ tha $\left.^{-1}\right)$ with harvest index of $27.0 \%$ which is also economically profitable (BCR 3.84 and MRR 18.05\%). Considering all, USG at rate $160 \mathrm{~kg} \mathrm{~N} \mathrm{ha}^{-1}$ with three ton poultry manure i.e. $\mathrm{N}_{126} \mathrm{P}_{22} \mathrm{~K}_{62} \mathrm{~S}_{14} \mathrm{Zn}_{2} \mathrm{~B}_{1} \mathrm{Mo}_{0.8} \mathrm{~kg} / \mathrm{ha}+3 \mathrm{t} / \mathrm{ha}$ $\mathrm{PM}$ or prilled urea (PU) at rate $180 \mathrm{~kg} \mathrm{~N} \mathrm{ha}^{-1}$ with three ton poultry manure i.e. $\mathrm{N}_{146} \mathrm{P}_{22} \mathrm{~K}_{62} \mathrm{~S}_{14} \mathrm{Zn}_{2} \mathrm{~B}_{1} \mathrm{Mo}_{0.8 \mathrm{~kg} / \mathrm{ha}}+3 \mathrm{t} / \mathrm{ha} \mathrm{PM}$ can be recommended for profitable broccoli production.

\section{REFERENCES}

Abou El-Magd, M.M., El-Bassiony, A.M. \& Fawzy, Z.F. 2006. Effect of organic manure with or without chemical fertilizers on growth, yield and quality of some varieties of broccoli plants. Journal of Applied Sciences Research 2(10): 791-798.

Babik, I. \& Elkner, K. 2002. The effect of nitrogen fertilization and irrigation on yield and quality of broccoli. Acta Horticulture 571(2): 33-43.

Bahadur, A., Singh, J., Upadhyay, A.K. \& Singh, K.P. 2003. Effect of organic manures and biofertilizers on growth, yield and quality attributes of broccoli (Brassica oleracea L. var./Italica Plenck). Vegetable Science 30(2): 192-194.

Bangladesh Agricultural Research Council. 2012. Fertilizer Recommendation Guide-2012. (ISBN: 978-984-500-000-0). Dhaka, Bangladesh: BARC.

Basel, A., Atif, O. \& Mahadeen, Y. 2008. Effect of fertilizers on growth, yield, yield components, quality and certain nutrient contents in broccoli (Brassica oleracea). International Journal of Agriculture and Biology 10(6): 627-632.

Belec, C., Villeneuve, S., Coulombe, J. \& Tremblay, N. 2001. Impact of nitrogen fertilization on yield, hollow stem incidence and sap nitrate concentration in broccoli. Canadeian Journal of Plant Sciience 81(4): 765-772.

Bhardwaj, A.K., Kumar, P. \& Singh, R.K. 2007. Response of nitrogen and pre-planting treatment of seedlings with the azotobacter on growth and productivity of broccoli (Brassica oleracea var. Italica). The Asian Journal of Horticulture 2(1): 15-17.

Dass, A., Lenka, N.K., Patnaik, U.S. \& Sudhishri, S. 2008. Integrated nutrient management for production, economics and soil improvement in winter vegetables. International Journal of Vegetable Science 14(2): 104120.

Dauda, S.N., Ajayi, F.A. \& Ndor, E. 2008. Growth and yield of water melon (Citrullus lanatus) as affected by poultry manure application. Journal of Agriculture and Social Science 4(3): 121-224.

Decoteau, D.R. 2000. Vegetable Crops. New Jersey: Prentice Hall.

Kumar, M., Kumari, P., Ojha, R.K., Kumar, A. \& Prasad, K.K. 2012. Effect of temperature on growth and yield of broccoli under integrated nutrient management. Progressive Horticulture 44(2): 307-312.

Lawlor, D.W. 2002. Carbon and nitrogen assimilation in relation to yield: Mechanisms are the key to understanding production systems. Journal of Experimental Botany 53(370): 773-787.

Liu, L., Shelp, B.J. \& Spiers, G.A. 1993. Boron distribution and translocation in field-grown broccoli (Brassica oleracea var. Italica). Canadian Journal of Plant Science 73(2): 587600 .
Maurya, A.K., Singh, M.P., Srivastava, B.K., Singh, Y.V., Singh, D.K., Singh, S. \& Singh, P.K. 2008. Effect of organic manures and inorganic fertilizers on growth characters, yield and economics of sprouting broccoli cv. Fiesta. Indian Journal of Horticulture 65(1): 116-118.

Ouda, B.A. \& Mahadeen, A.Y. 2008. Effect of fertilizers on growth, yield, yield components, quality and certain nutrient contents in broccoli (Brassica oleracea). International Journal of Agriculture and Biology 10(6): 627-632.

Perrin, P.K., Winkelman, D.L., Moseardi, E.R. \& Anderson, J.R. 1979. Farm Agronomic Data for Farmer's Recommendation. Information Bulletin. CIMMYT, Mexico: CIMMYT.

Rakesh, S., Chaurasia, S.N.S. \& Singh, S.N. 2006. Response of nitrogen sources and spacing on growth and yield of broccoli (Brassica aleracea var. Italica plenck). Vegetable Science 33(2): 198-200.

Shangguan, Z., Shao, M. \& Dyckmans, J. 2000. Effects of nitrogen nutrition and water deficit on net photosynthetic rate and chlorophyll fluorescence in winter wheat. Journal of Plant Physiology 156(1): 46-51.

Sreelatha, T., Raju, A.S. \& Raju, A.P. 2006. Effect of different doses of farm yard manure and poultry manure and their interaction with fertilizer nitrogen on yield and nutrient uptake in mesta-rice cropping system. The Journal of Research Angrau 34(1): 41-47.

Steel, R.G.D. \& Torrie, J.H. 1980. Principles and Procedures of Statistics: A Biometrical Approach. New York: McGraw Hall.

Suresh, K.D., Sneh, G., Krishn, K.K. \& Mool, C.M. 2004. Microbial biomass carbon and microbial activities of soils receiving chemical fertilizers and organic amendments. Archives of Agronomy and Soil Science 50(7): 641-647.

Tandon, H. 1995. Methods of Analysis of Soil, Plants, Waters and Fertilizer. New Delhi: Fertilizers Development and Consultation Organization.

Yoldas, F., Ceylan, S., Yagmur, B. \& Mordogan, N. 2008. Effect of nitrogen fertilizer on yield quality and nutrient content in broccoli. Journal of Plant Nutrition 31(7): 1333-1343.

Zaman, S.K., Razzaque, M.A., Karim, S.M.R. \& Ahmed, A.U. 1993. Evaluation of prilled urea and urea super granule as nitrogen sources for upland aus rice. Bangladesh Rice Journal 4(1\&2): 42-46.

Md. Jamal Hussain

Soil \& Water Management Section

Horticulture Research Centre

Bangladesh Agricultural Research Institute

Gazipur

Bangladesh

A.J.M. Sirajul Karim, A.R.M. Solaiman \& Md. Shafiqul Islam Department of Soil Science

Bangabandhu Sheikh Mujibur Rahman Agricultural University Gazipur

Bangladesh

Md. Monirul Islam

Tuber Crops Research Centre

Bangladesh Agricultural Research Institute

Gazipur

Bangladesh 
Laila Naher*

Faculty of Agro-based Industry

Universiti Malaysia Kelantan

17600 Jeli, Kelantan Darul Naim

Malaysia

Laila Naher*

Institute of Food Security and Sustainable Agriculture

Universiti Malaysia Kelantan

17600 Jeli, Kelantan Darul Naim

Malaysia
*Corresponding author; email: lailanaher@umk.edu.my

Received: 12 May 2019

Accepted: 24 October 2019 
